\title{
Review of Polygeneration Schemes with Solar Cooling Technologies and Potential Industrial Applications
}

\author{
Andrés Villarruel-Jaramillo ${ }^{1, *(\mathbb{D}}$, Manuel Pérez-García ${ }^{2} \mathbb{D}$, José M. Cardemil ${ }^{1} \mathbb{C}$ and Rodrigo A. Escobar ${ }^{1,3}$ \\ 1 Departamento de Ingeniería Mecánica y Metalúrgica, Escuela de Ingeniería, Pontificia Universidad Católica \\ de Chile, Vicuña Mackenna 4860, Santiago 7820436, Chile; jmcardem@uc.cl (J.M.C.); \\ rescobar@ing.puc.cl (R.A.E.) \\ 2 CIESOL Research Center on Solar Energy, Joint Center UAL-CIEMAT, University of Almeria, Ctra. \\ Sacramento s/n, 04120 Almería, Spain; mperez@ual.es \\ 3 Centro del Desierto de Atacama, Pontificia Universidad Católica de Chile, Vicuña Mackenna 4860, \\ Santiago 7820436, Chile \\ * Correspondence: afvillarruel@uc.cl
}

Citation: Villarruel-Jaramillo, A.; Pérez-García, M.; Cardemil, J.M.;

Escobar, R.A. Review of

Polygeneration Schemes with Solar Cooling Technologies and Potential Industrial Applications. Energies 2021, 14, 6450. https://doi.org/10.3390/ en14206450

Academic Editor: Pedro Dinis Gaspar

Received: 7 September 2021

Accepted: 6 October 2021

Published: 9 October 2021

Publisher's Note: MDPI stays neutral with regard to jurisdictional claims in published maps and institutional affiliations.

Copyright: (c) 2021 by the authors. Licensee MDPI, Basel, Switzerland. This article is an open access article distributed under the terms and conditions of the Creative Commons Attribution (CC BY) license (https:/ / creativecommons.org/licenses/by/ $4.0 /)$.

\begin{abstract}
The trend to reduce $\mathrm{CO}_{2}$ emissions in cooling processes has made it possible to increase the alternatives for integrating solar energy with thermal equipment whose viability depends on its adaptation to polygeneration schemes. Despite the enormous potential offered by the industry for cooling and heating processes, solar cooling technologies (SCT) have been explored in a limited way in the industrial sector. This work discusses the potential applications of industrial SCTs and classifies hybrid polygeneration schemes based on supplying cold, heat, electricity, and desalination of water; summarizes the leading SCTs, and details the main indicators of polygeneration configurations in terms of reductions on primary energy consumption and payback times. To achieve an energy transition in refrigeration processes, the scenarios with the most significant potential are: the food manufacturing industry (water immersion and crystallization processes), the beverage industry (fermentation and storage processes), and the mining industry (underground air conditioning).
\end{abstract}

Keywords: solar cooling technology; polygeneration schemes; industrial cooling processes; photovoltaic; solar collector

\section{Introduction}

The main world organizations have focused on reducing the $\mathrm{CO}_{2}$ emissions associated with electricity generation through the implementation of policies and incentives that promote renewable energies (RE) [1]. The International Energy Agency (IEA) projected that with current policies, it is possible to increase the share of renewable energies from $36 \%$ to $52 \%$ by 2050 . However, it proposes reaching $84 \%$ as a response to the climate crisis [2]. Another strategy is to reduce the electricity demand from key high-consumption processes by implementing energy-saving, passive, or more efficient solutions. According to the IEA, one of these high-consumption processes is cooling processes (RP), which consumed 2075 TWh of electricity in 2018, accounting for $10 \%$ of the world's energy consumption. If the current trend of refrigeration energy consumption continues, in 2040, demand could triple the current level [2-4]. Consequently, such continuous growth will hinder the decarbonization goals in the electricity sector $[2,5,6]$. Part of the strategies for reducing the electricity consumption in RPs considers policies along three lines: energy-efficient buildings, optimization of conventional refrigeration equipment (CRS) and investigation of alternative cooling equipment $[7,8]$.

For this reason, research has been directed towards driving RPs by RE to reduce the dependence on the electricity grid. Solar energy has advantages over wind, geothermal or nuclear power due to its adaptability in installation, reduced costs, and availability of resources even in remote areas. The most recurrent renewable sources for alternative 
cooling equipment are solar photovoltaic (PV) and solar thermal (ST) [9]. In particular, PVs tend to be used primarily for the advantage of adapting to previously installed electrical cooling equipment. Furthermore, PVs are attractive in the residential sector due to the increased efficiency and the current trend in cost reduction. However, the overall efficiency of a PV system in heat processes tends to decrease due to the conversion efficiency for heat processes. For this reason, electricity supply strategies with PVs are oriented towards conventional cooling equipment and supplying electricity to equipment connected to the grid. From the point of view of heat processes, the use of solar collectors (SC) makes it possible to increase the solar fraction by improving the techno-economic relationship of the system.

Previous reviews regarding solar thermal cooling technologies have focused on the operating principles, working temperatures and equations of state of the adsorption [10-13], absorption [14-16], and thermomechanical $[17,18]$ machines. In addition, the technical limits of the operational aspects and the conversion efficiency were detailed [11,19-21]. For reducing heat losses or improving the operating strategies of cooling equipment, the hybridization of sorption equipment and its design strategies were also evaluated [22-25]. Although several novel prototypes for solar cooling technologies have been developed in recent years, the focus has been in increasing the coefficient of performance (COP) with little consideration for the economic aspects of its construction. which can raise costs substantially, having a potentially significant effect in technological selection. However, several other studies have evaluated the technical and economic performance of solar cooling technologies to analyze how well they can perform when compared to conventional cooling systems $[22,26]$. These evaluations have been mainly done on residential cases of study, which have focused on air-conditioning processes highlighting design optimization methods, supply strategies, and the architectural integration of solar energy in buildings for cooling [27-29]. This fact, along with the previous argument, have resulted in a limited vision of the potential of solar cooling technologies applied to other commercial or industrial settings, where the potential to significantly impact $\mathrm{CO}_{2}$ reduction is considerable. In particular, solar thermal cooling has economic disadvantages when compared to conventional systems. Thermal cooling equipment driven by SC is expensive due to low conversion efficiency requiring high $\mathrm{CO}_{2}$ tax for its economic feasibility with respect to conventional equipment. Therefore, one could argue that it is necessary to integrate solar cooling with heating processes to improve the joint techno-economic performance [30].

The feasibility of the application of the systems depends on the ability to maximize the use of the solar field. In this perspective, the trend in the design and evaluation of polygeneration plants has increased in recent years, but has focused so far on the residential sector [9]. The reviews conducted on polygeneration have focused on evaluating in the residential sector the simultaneous supply of cooling, electricity and heating with combined PV-SC schemes and the integration of photovoltaic thermal systems (PVT). In addition, the possibility of its adaptation to the market based on primary energy savings and $\mathrm{CO}_{2}$ reduction compared to a conventional system has grown [9,31-33]. However, studies focusing on residential sector are significantly different in terms of the thermal loads observed for the industrial sector. This is because the industry requires temperature control in processes that vary between $<0^{\circ} \mathrm{C}$ to $>30^{\circ} \mathrm{C}$. Industrial processes like deodorization, pasteurization, crystallization, refrigeration, etc. can work simultaneously. In addition, due to quality standards, temperatures must be kept constant despite external and internal changes due to climatic seasons or variations in the volume of the product.

In this sense, the most widely used alternative equipment are reversible heat pumps and absorption cooling equipment. Consequently, solar cooling systems have been evaluated in the residential sector to supply cold with sorption equipment with a nominal capacity greater than $1000 \mathrm{~kW}$, comparable to cooling equipment used in the mid-scale food industry [34].

In addition to the above, except for the agro-industry and food industry, solar refrigeration applied in the industrial sector has hardly been investigated despite the strict 
requirements of constant temperature control and the high energy demand in refrigeration processes [35-37]. In the current context of a reduction of the environmental impact of productive activities, the possibility of optimizing RE integration in RP by the adoption of polygeneration schemes as well as the huge potential that industries offer in terms of the magnitude and the multiplicity of their energy demands make it interesting to review the main solar cooling technologies adapted to polygeneration schemes and to discuss their potential integration in the industrial sector.

This work, after providing a technical and historical overview of development of the refrigeration equipment and the ways in which they can use solar energy as a primary energy source, includes a comprehensive analysis of the scientific literature on how solar cooling systems can be integrated into hybrid schemes for cooling, heating, electricity, and desalinated water. In addition, aiming to serve as a reference for project implementation this work also analyses the published figures of the key techno-economical indexes for these systems as well as the realizations and case studies implemented all over the world.

\section{Historical Evolution of Cooling Equipment and Main Solar Cooling Technologies}

Studies of cooling processes for their integration with solar energy have grown consistently during the last 40 years due to the benefits of harnessing solar radiation as a source of direct renewable energy [30,38-40]. The operating principles and first patents began to be developed in the 19th century. Regarding solar energy, absorption equipment (ABS) was the first to be integrated with solar collectors (SC) [10,26,41]. However, the low costs of coal added to the technological limitations of SC and the temperature control system relegated ABS to rural applications during the first half of the 20th century $[42,43]$. Furthermore, in the same period, commercial alternatives to adsorption equipment (ADS) emerged that were economically more attractive on a small scale than ABS [42,44]. On the other hand, vapor compression cycle (VCC) cooling equipment has remained the leading technology since the beginning of the 20th century due to the adaptation of VCC to electric currents $[43,45,46]$. Research on solar energy for cooling processes was resumed due to the oil crisis in 1973 and the restrictions on chlorofluorocarbon refrigerants (CFCs) with the Montreal Protocol $[26,27,43]$. The first evaluations of photovoltaic refrigeration (PVR) configurations emerged in the 1970s and have been evaluated in vaccine storage, air conditioning in residential buildings, and vehicles [47-50]. PVRs can achieve primary energy savings of between $20 \%$ and $70 \%$ due to the supply of electricity to other equipment when the CRS is not in operation [51,52]. In recent years, studies have focused on reversible heat pump systems and the removal of the battery set for direct drives, reducing the investment cost of the system by up to $84 \%$ [53-55].

In the 1970s, new proposals for solar-powered equipment, such as Stirling refrigeration equipment (SCE), emerged. Although ECSs were marketed during the first half of the 20th century with an electric drive, prototypes were also developed for their drive with thermal energies using the reversible liquid piston cycle [18,56-60]. Research has focused on improving performance by modifying the geometry of the evaporator and condenser, increasing performance up to $32 \%$ [61]. Furthermore, working fluids, such as hydrogen, have been tested to reach a COP of 0.53, similar to commercial ADS machines [62]. However, the integration with solar heat remains at the stage of evaluating the performance of the equipment using solar collectors. and Fresnel lenses [22,58,63].

Another device developed was thermoelectric devices (TE) in the 1940s for electricity generation and, later modified for refrigeration (TEC) in the military industry [64,65]. The devices have the advantage of working with direct current, which facilitates their integration with PV panels [66-69]. However, due to the low efficiency of TEC, studies have focused on developing materials that enable improving ZT efficiency, which is an indicator relating the material to thermal conductivity, electrical conductivity, and Seebeck coefficient as a function of device temperature [70]. In recent years, TECs have been integrated into photovoltaic modules with Fresnel lenses to dissipate heat in PV plants [71-73]. In addition, TECs were combined with PV panels for applications of refrigeration, freezing and radiant 
walls in buildings $[22,29,33,64,74,75]$. The prototypes integrated into the façade of buildings are called building-integrated photovoltaic thermoelectric (BIPVT) [76-78]. BIPVTs in clear sky conditions in summer reach peaks in electricity consumption savings of up to $100 \%$ compared to a CRS [79-81]. Furthermore, devices have been designed that replace the condenser-evaporator assembly with the TEC and are integrated with a TES for heating in a CRS. The configuration manages to reduce electricity consumption by up to $8.5 \%$ compared to the CRS $[82,83]$. Despite the technical advantages due to the small size, the possibility of reaching freezing temperatures, and the lack of moving parts, the TEC lacks an analysis of the economic sensitivity with respect to other solar cooling technologies.

Ejector cooling systems (EJC) have been evaluated since the 1970s but became more relevant during the 1990s [26,84-86]. The EJCs are sensitive to meteorological variations and the size of the solar field, being of interest to improve the global COP of the system (SC-TES) -EJC [17,87-91]. In this sense, the use of cold storage with phase change material (PCM) and a variable geometry ejector nozzle is proposed [92-96]. However, increased components and a more robust control system can negatively affect equipment costs $[97,98]$. In addition, EJC systems integrated into reversible heat pumps and the heat supply for sanitary water have been developed [99-101]. In addition, the EJCs have been evaluated by substituting the R141b refrigerant for isobutane, reducing the EJC of the generator temperature to ranges below $80^{\circ} \mathrm{C}$, achieving competitive performance against adsorption cycles $[102,103]$.

At the beginning of the 2000s, desiccant refrigeration equipment (DES) was developed, operation of which is based on sorption and desorption processes [104]. DES has been tested for low-irradiation tropical environments, but DES efficiency is highly sensitive to relative humidity $[21,105]$. On the other hand, ADS equipment can be classified like adsorption by phisisorption (ADS-PH) and adsorption by chemisorption (ADS-CH). ADS equipment has been commercialized for small-scale domestic refrigeration and ice-making applications $[26,42,44]$. In addition, at the end of the 20th century and the beginning of the 21st, applications of solar ADS for food preservation and air conditioning for bus and train locomotives have deepened $[20,22,40,106]$. Similarly, ABS equipment since the late 1970s is being evaluated for HVAC applications, vaccine storage, and food preservation. ABS equipment can be classified like ABS of half effect (ABS-HE), ABS of simple effect (ABS-SE), ABS of double effect (ABS-DE) and generation absorption heat exchange (ABSGAX) $[10,38]$.

Despite the potential of alternative cooling equipment, heat-driven solar cooling systems have not achieved significant market penetration. According to general review articles focused on the design and operation of solar cooling, systems are significantly affected in the short and long term due to the natural variability of the solar resource $[25,28,31,105]$. Therefore, to overcome climate variability, systems require thermal storage (TES) and large solar fields that increase the initial investment cost. Consequently, at the end of the 2010s, solar heat cooling was considered unfeasible for the urban sector and PV-VCC systems were positioned as the best option for the residential sector [51,107,108].

However, with the declining costs of solar technology in recent years, research on optimizing energy delivery and demand has been highlighted to improve the viability of sorption systems $[11,102,109]$. New prototypes have also been developed, and the working fluids have been evaluated to decrease the generation temperature or increase the COP, as shown in Table 1. In addition, the trend to hybridize refrigeration equipment such as ADS-ABS, ABS-VCC, ABS-VCC, EJC-ABS, EJC-ADS, EJC-VCC to improve system performance and decrease generator temperature open alternatives to maximize solar field energy $[12,23,24,31,110]$. 
Table 1. Sorbent/refrigerant prototyping and testing of sorption cooling equipment.

\begin{tabular}{cccccccc}
\hline Ref. Technology & $Q_{c h}[\mathbf{k W}]$ & COP & $T_{G e n}\left[{ }^{\circ} \mathrm{C}\right]$ & $T_{E v a p}\left[{ }^{\circ} \mathbf{C}\right]$ & Work Flow & Scope \\
\hline [111] & ADS-PH & 0.371 & 0.293 & 85 & 14 & $\begin{array}{c}\text { Zeolite } \\
13 \mathrm{X} / \mathrm{CaCl}_{12}\end{array}$ & $\begin{array}{c}\text { The } 13 \mathrm{X} \text { zeolite } / \mathrm{CaCl}_{2} \text { pair work reduces } \\
\text { the COP of the equipment but increases the } \\
\text { specific cooling power by } 30 \% \text { compared to } \\
\text { the silica gel. }\end{array}$ \\
\hline [112] & ADS-PH & NA & 0.139 & 100 & 26 & $\begin{array}{c}\text { Nano- } \\
\text { activated } \\
\text { car- } \\
\text { bon/methanol }\end{array}$ & $\begin{array}{c}\text { Adding carbon nanoparticles (NMAC) to } \\
\text { activated carbon increased the adsorption } \\
\text { capacity by 33\%. }\end{array}$ \\
\hline
\end{tabular}

\begin{tabular}{|c|c|c|c|c|c|c|c|}
\hline [113] & ADS-PH & NA & 0.329 & 110 & 5 & $\begin{array}{c}\text { Silica } \\
\text { gel/water, } \\
\text { ethanol, } \mathrm{NH}_{3}\end{array}$ & $\begin{array}{l}\text { The adsorbents with the best } \\
\text { technoeconomic performance and the } \\
\text { minor environmental damage for air } \\
\text { conditioning and cold storage applications } \\
\text { are } \mathrm{AC}, \mathrm{ACF} \text { and } \mathrm{SiO}_{2} \text {. }\end{array}$ \\
\hline [114] & ADS-PH & $1-2$ & 0.24 & $53,1-75,3$ & 16 & $\begin{array}{c}\text { Zeolite } \\
\text { 13X/CaC } 12\end{array}$ & $\begin{array}{c}\text { Using the electrostatic coating method } \\
\text { with } 13 \mathrm{X} \text { zeolite } / \mathrm{CaCl}_{2} \text { coated adsorbents } \\
\text { and adding a preheat phase, the cooling } \\
\text { capacity improves by } 92.5 \% \text {. }\end{array}$ \\
\hline [115] & ADS-PH & 0.8 & 0.63 & 94.85 & 9.85 & $\begin{array}{c}\text { Silica } \\
\text { gel/water }\end{array}$ & $\begin{array}{l}\text { A device was designed to operate } \\
\text { continuously during night and day by } \\
\text { adapting three adsorption/desorption } \\
\text { beds that are activated depending on the } \\
\text { energy available in the generator. }\end{array}$ \\
\hline [116] & AD-PH & NA & 0.47 & 80 & - & Zeolite/Water & $\begin{array}{l}\text { A method was developed to estimate the } \\
\text { performance of an ADS composed of } \\
\text { multiple modules by a full-scale analysis of } \\
\text { one tube containing multiple tubes with } \\
\text { hundreds of fins. }\end{array}$ \\
\hline [117] & ADS-PH & NA & 0.14 & 92.35 & - & $\begin{array}{l}\text { Activated car- } \\
\text { bon/methanol }\end{array}$ & $\begin{array}{c}\text { A numerical model was developed that can } \\
\text { be adapted with another type of adsorbate } \\
\text { to evaluate the performance of a tubular } \\
\text { adsorption system with solar energy. }\end{array}$ \\
\hline [118] & ADS-CH & 0.15 & 0.15 & 105 & - & $\begin{array}{c}\mathrm{CaCl}_{2} / \mathrm{AC}- \\
\text { Ammonia }\end{array}$ & $\begin{array}{l}\text { A prototype ice maker was evaluated for } \\
\text { producing } 50 \mathrm{~kg} \text { of ice in summer. The } \\
\text { system can operate without valve control, } \\
\text { in a simple combination with the storage } \\
\text { tank. The prototype could be viable for } \\
\text { industrial or residential applications. }\end{array}$ \\
\hline [119] & ADS-CH & 1.4 & 0.33 & 70 & 10 & $\begin{array}{c}\mathrm{NaBr} / \mathrm{EG}- \\
\mathrm{NH}_{3}\end{array}$ & $\begin{array}{l}\text { An adsorption chiller was designed that } \\
\text { uses a compound made of sodium bromide } \\
\text { impregnated in expanded graphite as a } \\
\text { sorbent and ammonia as a coolant. }\end{array}$ \\
\hline [120] & ADS-CH & $\begin{array}{c}0.656 \\
\mathrm{~kW} / \mathrm{kg}\end{array}$ & 0.5 & 110 & 0 & $\begin{array}{l}\mathrm{SrC}_{12}- \\
\text { expanded } \\
\text { graphite } \\
\text { composite }\end{array}$ & $\begin{array}{l}\text { The strontium chloride }(\mathrm{SrCl} 2) / \mathrm{NH}_{3} \\
\text { working pair was evaluated, impregnating } \\
\text { the expanded graphite } \mathrm{SrCl}_{2} \text { to determine } \\
\text { the thermodynamic equilibrium properties } \\
\text { with different concentrations and fitting a } \\
\text { kinetic model employing a small-scale } \\
\text { experimental prototype }\end{array}$ \\
\hline [121] & ADS-PCM & $\begin{array}{c}\text { C: } 47 W \& \\
\text { H: } 47\end{array}$ & 0.42 & NA & NA & $\mathrm{LiCl}$ & $\begin{array}{c}\text { The performance of a chiller prototype for } \\
\text { cooling and heating applications that } \\
\text { integrates ADS equipment with vacuum } \\
\text { tubes and phase change material is } \\
\text { evaluated. }\end{array}$ \\
\hline
\end{tabular}


Table 1. Cont

\begin{tabular}{|c|c|c|c|c|c|c|c|}
\hline Ref. & Technology & $Q_{c h}[\mathrm{~kW}]$ & $\mathrm{COP}$ & $\mathrm{T}_{\mathrm{Gen}}\left[{ }^{\circ} \mathrm{C}\right]$ & $T_{\text {Evap }}\left[{ }^{\circ} \mathrm{C}\right]$ & Work Flow & Scope \\
\hline [122] & ABS-SE & 3.2 & 0.53 & 180 & 13 & $\mathrm{NH}_{3}$ & $\begin{array}{c}\text { A compact } \mathrm{ABS}\left(\mathrm{NH}_{3}\right) \text { equipment was } \\
\text { designed with mass exchangers and } \\
\text { monolithic microscale exchange for space } \\
\text { conditioning. }\end{array}$ \\
\hline [123] & ABS-SE & NA & 0.61 & - & - & $\mathrm{NH}_{3}$ & $\begin{array}{c}\text { The generator was redesigned by changing } \\
\text { the heat exchanger for a column of a } \\
\text { bundle of tubes that allows a distributed } \\
\text { heat transfer to improve waste and } \\
\text { low-quality heat utilization. }\end{array}$ \\
\hline [124] & $\begin{array}{c}\text { GAX Split } \\
\text { ABS }\end{array}$ & 39.8 & $\begin{array}{c}0.55- \\
0.95\end{array}$ & 160 & -30 & $\mathrm{NH}_{3}$ & $\begin{array}{l}\text { A heat recovery configuration of an } \\
\text { ABS-GAX split was developed for unified } \\
\text { operation for space heating, air } \\
\text { conditioning, and refrigeration } \\
\text { applications. }\end{array}$ \\
\hline [125] & ABS-DL & 2.5 & & 0.3 & 7 & $\mathrm{NH}_{3}$ & $\begin{array}{l}\text { A double lift cycle is experimentally } \\
\text { evaluated under different operating } \\
\text { conditions that modify the COP, including } \\
\text { generator temperature, fan speed, and } \\
\text { evaporator temperature. }\end{array}$ \\
\hline [126] & $\begin{array}{c}\text { ABS } \\
\text { Semi-Gax }\end{array}$ & $2.20-2.33$ & & $\begin{array}{c}0.455- \\
0.428\end{array}$ & 7 & $\mathrm{NH}_{3}$ & $\begin{array}{l}\text { The COP can be optimized by adjusting } \\
\text { the intermediate pressure through the split } \\
\text { ratio at each air temperature. }\end{array}$ \\
\hline [127] & ABS GAX-DL & 1.88 & & 0.25 & -5 & $\mathrm{NH}_{3}$ & $\begin{array}{c}\text { The design of a double lift ABS device with } \\
\text { two self-adjusting pumps was evaluated to } \\
\text { operate with evaporation temperatures } \\
\text { below } 0{ }^{\circ} \mathrm{C} \text {. }\end{array}$ \\
\hline [128] & ABS GAX-DL & 39.2 & & 0.308 & -30 & $\mathrm{NH}_{3}$ & $\begin{array}{c}\text { The maximum internal heat recovery of an } \\
\text { ABS-DL coupled to mass is evaluated by } \\
\text { the pinch method. }\end{array}$ \\
\hline [129] & $\begin{array}{c}\text { ABS } \\
\text { Semi-Gax }\end{array}$ & NA & 0.494 & 90 & 5 & $\mathrm{NH}_{3}$ & $\begin{array}{c}\text { Five air absorption refrigeration prototypes } \\
\text { were evaluated to determine design } \\
\text { parameters based on the risk of } \\
\text { crystallization. }\end{array}$ \\
\hline [130] & EJE-ABS & 10 & 0.95 & 185-215 & 7 & $\mathrm{LiBr}$ & $\begin{array}{l}\text { ABS-EJC works with two heat sources at } \\
\text { different temperatures; a } 20 \% \text { increase in } \\
\text { COP was achieved compared to ABS-SE. }\end{array}$ \\
\hline [131] & EJE-ABS & 100 & 1.65 & 246.4 & 12.5 & $\mathrm{LiBr}$ & $\begin{array}{l}\text { An EYC-ABS system integrated with } \\
\text { parabolic trough collectors was evaluated } \\
\text { and it was determined that the } \\
\text { performance reached an increase of up to } \\
60.78 \% \text { compared to conventional ABS. }\end{array}$ \\
\hline [132] & SE-DE & 91-134 & 0.88 & $105-150$ & $8.4-7$ & $\mathrm{LiBr}$ & $\begin{array}{l}\text { The hybridization allows increasing the } \\
\text { COP from } 0.79 \text { to } 1.09 \text { with inlet } \\
\text { temperatures lower than } 155^{\circ} \mathrm{C} \text {. }\end{array}$ \\
\hline
\end{tabular}

Figure 1 shows a timeline that marks significant advances in the development of solar cooling equipment. In the last decade, research has intensified to improve the viability of solar cooling processes for urban applications with polygeneration plants. The intention is to maximize the continuous use of the energy generated by the solar field, which is characteristic of residential applications that supply process heat, refrigeration, and electricity production $[9,133]$. 


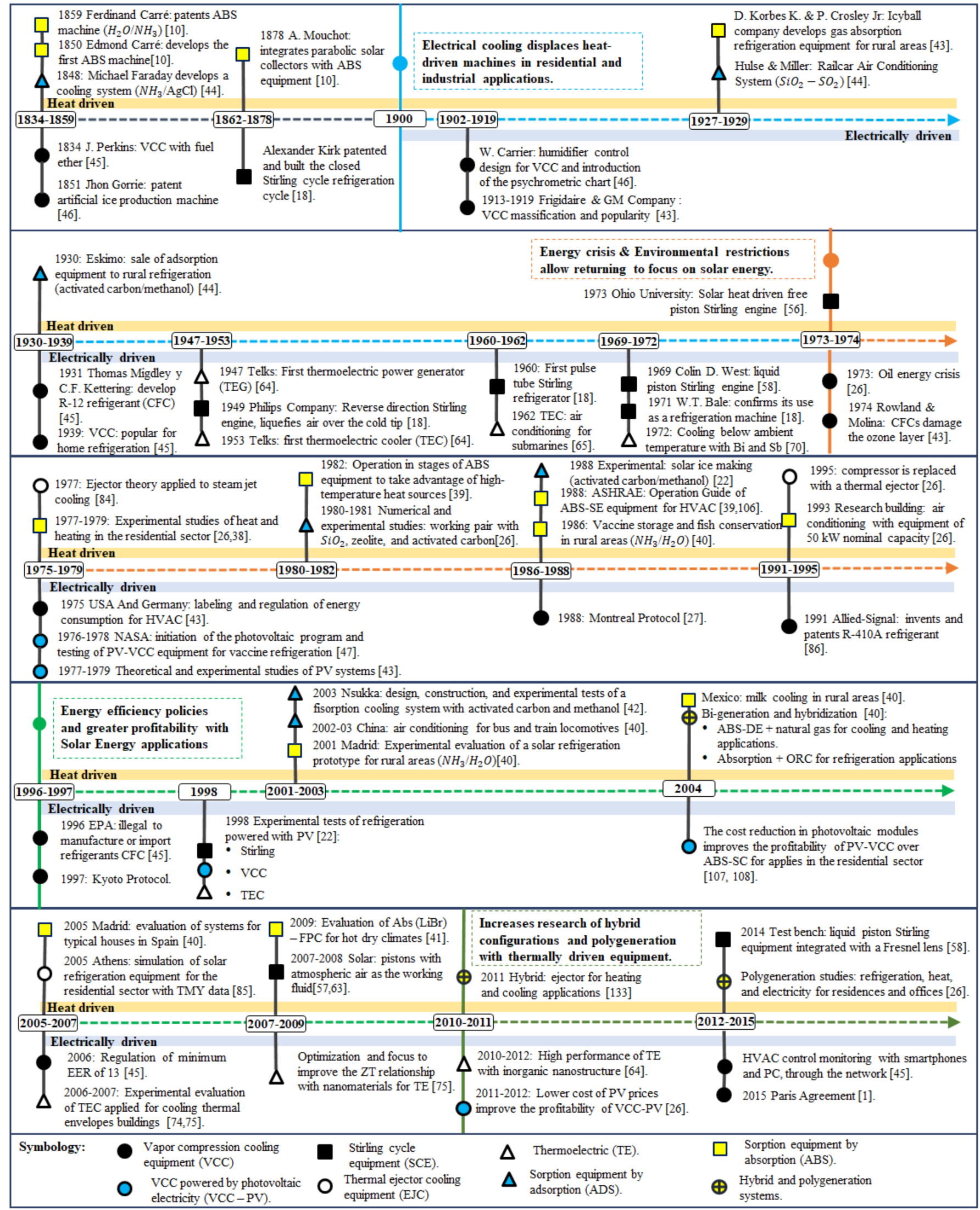

Figure 1. Timeline of the main cooling technologies according to their driving energy source. 
For this reason, the systems combine various energy sources such as PV panels, SC, biomass boilers, and geothermal energy that must be optimized to maximize primary energy savings $[32,134,135]$. However, to optimize the systems, it is necessary to select the cooling equipment by relating the nominal chiller power $\left(Q_{C h}\right)$ with the COP, generator temperature $\left(T_{G e n}\right)$ and evaporator temperature $\left(T_{E v a p}\right)$. According to the literature of the present review, Figures 2 and 3 detail the operating ranges of prototypes and the main commercial heat-driven cooling chillers. ADS by physisorption (ADS-Ph) equipment has a COP between $0.13-0.62$ and requires a $T_{G e n}$ between $50-130{ }^{\circ} \mathrm{C}$ [14,136-142]. The most widely used adsorbate-adsorbent is silica gel/water and reaches $T_{E v a p}$ of up to $5{ }^{\circ} \mathrm{C}[15,143-145]$.

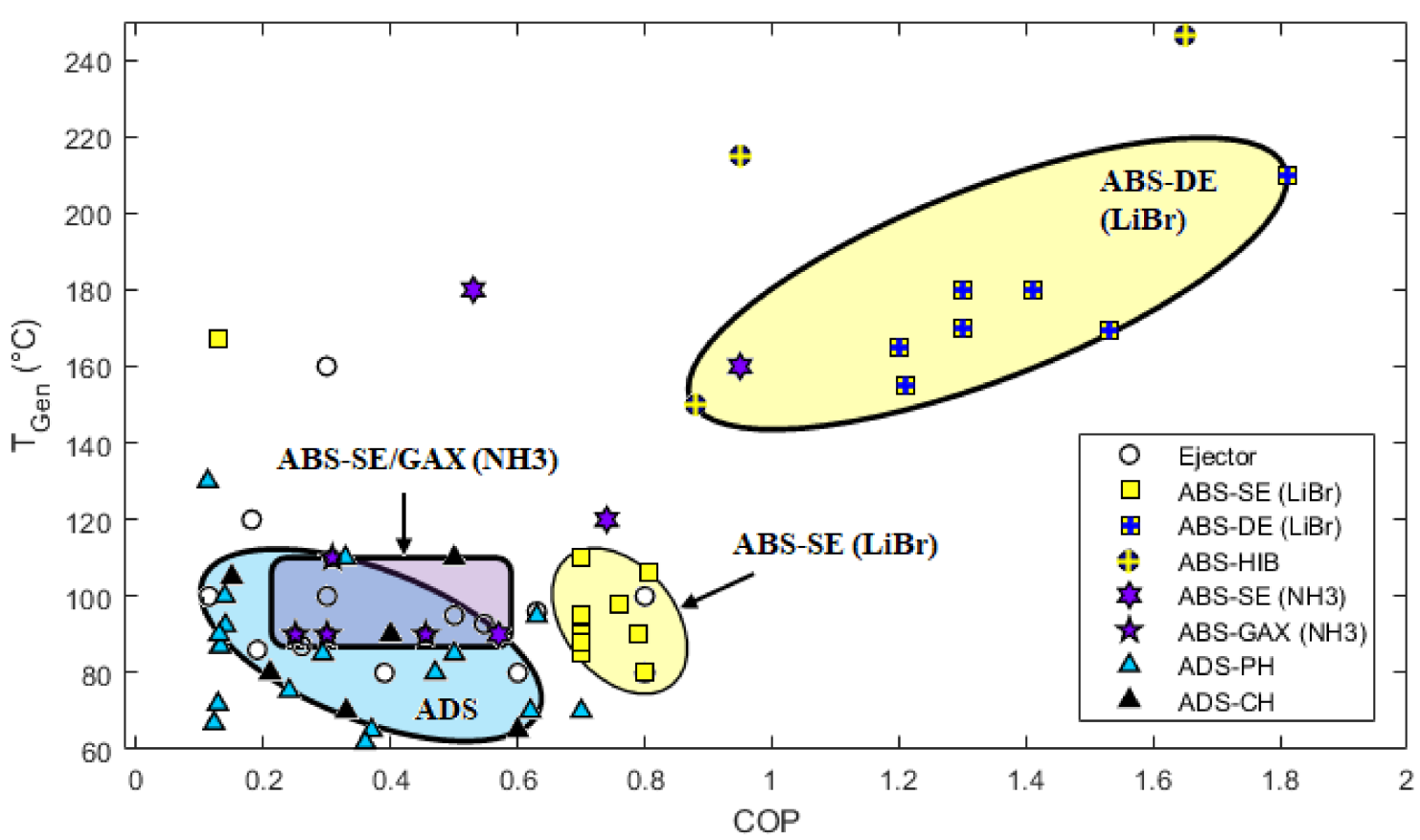

Figure 2. Nominal coefficient of performance (COP) vs. nominal operating temperature according to the studies in Sections 2 and 3.

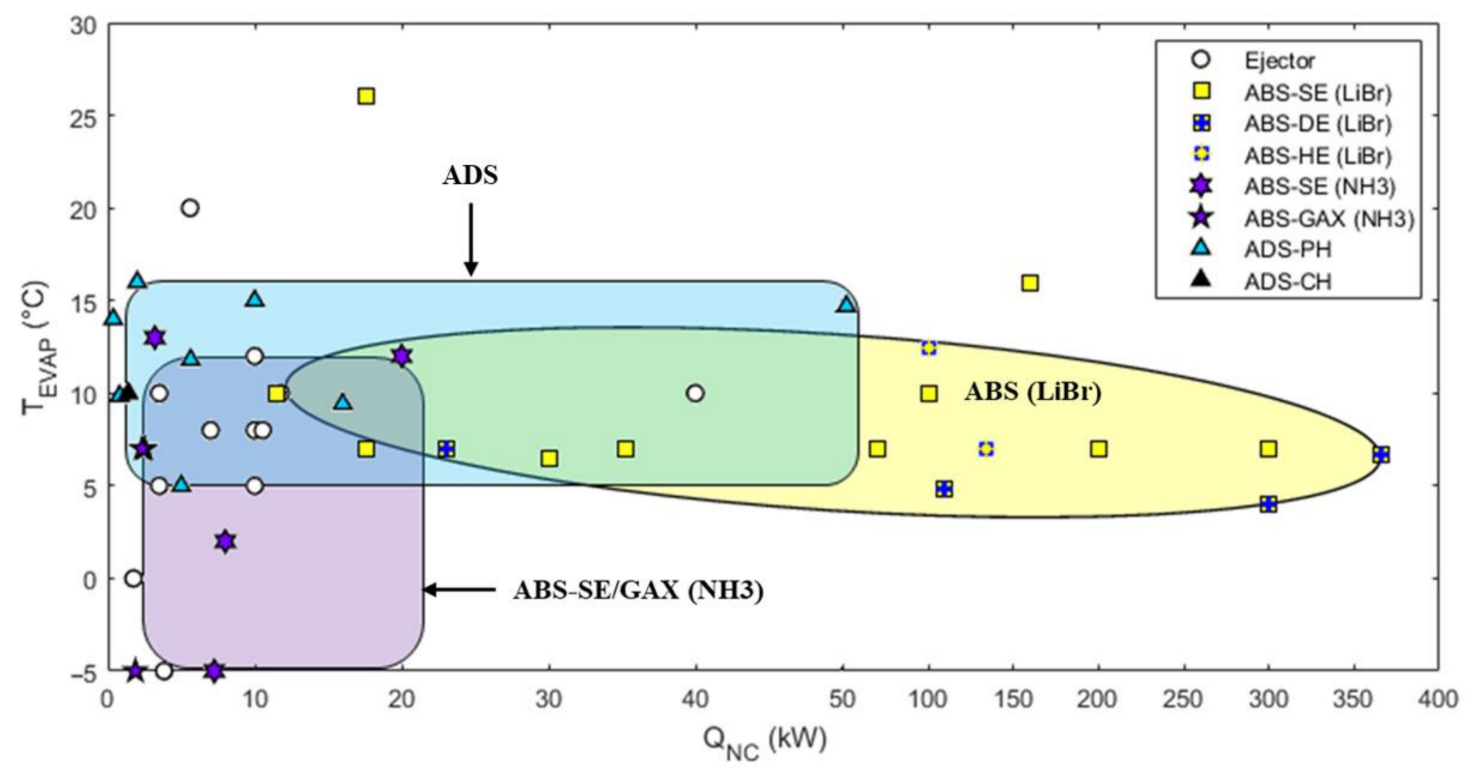

Figure 3. Evaporator temperature vs nominal capacity according to the studies in Sections 2 and 3. 
Systems with activated carbon/methanol have also been evaluated, but the COP and the $T_{G e n}$ increase with respect to silica gel/water [16,146-149]. In comparison, ABS equipment has a COP between $0.7-1.8$ and a $T_{G e n}$ between $80-220{ }^{\circ} \mathrm{C}[13,109,150,151]$. Before crystallization, using $\mathrm{LiBr} / \mathrm{H}_{2} \mathrm{O}$ as working fluid, the evaporator temperature is $5{ }^{\circ} \mathrm{C}$, while using $\mathrm{NH}_{3} / \mathrm{H}_{2} \mathrm{O}$ as working fluid, the system can reach temperatures as low as $-5{ }^{\circ} \mathrm{C}$ [152-158]. The difference in the performance of the ABS equipment of medium effect (ABS-HE), single effect (ABS-SE), double effect (DE-ABS) can be evaluated based on increasing the COP to optimize the heat received by the generator, reduce the risk of crystallization of the equipment due to low evaporator temperatures, or increase the cooling capacity [19,159-162].

\section{Polygeneration Schemes Integrated with Solar Cooling Technologies}

According to the literature, the feasibility of the success of heat-driven refrigeration equipment is directly related to the use of the energy supply from the solar field. In this sense, thermomechanical generators (TMG) have been evaluated for joint operation with VCC and reversible heat pumps (RHP) [163]. The systems are composed of an organic Rankine cycle generator (ORC) and concentration manifolds to deliver temperatures above $100{ }^{\circ} \mathrm{C}[164,165]$. However, TMGs are also subjected to polygeneration systems to achieve their economic viability. This section describes the main solar cooling studies integrated into the polygeneration scheme for cooling, heating, electricity, and desalinated water.

\subsection{Cooling Heat/Electricity Generation ( $\mathrm{CH} / \mathrm{E})$}

The generation of cold and heat or electricity $(\mathrm{CH} / \mathrm{E})$ combines two or more renewable energy sources such as SC, PV, or external sources such as biomass. Figure 4 shows the integration schemes for refrigeration-heat $(\mathrm{CH})$ or refrigeration-electricity $(\mathrm{CE})$. On the other hand, Table 2 summarizes the main configuration schemes. Table 2, like Figure 4, is divided according to solar technology $(\mathrm{SEH})$, auxiliary electric heating equipment $(\mathrm{EH})$, fuel for the auxiliary boiler (F), integration of auxiliary heat (I1), integration of heat generated by renewable sources (I2), unconventional refrigeration equipment (UR), electrical generation unit (GPU), conventional air-conditioning equipment (HVAC), energy consumption lines produced (I3), type of energy generated (generation), process (P), supply (S) and electricity generation (E). BIPVT applications have also been adapted for electricity supply and cooling; the excess electricity produced by the PV panel is used to power the electrical grid. Evaluations for residential applications show a 70\% potential to reduce heat from a typical wall [166]. Reversing the polarity of TEC also makes it possible to supply heat in winter, obtaining a COP of 0.45 with thermal efficiencies of $12.06 \%$ and electrical efficiencies of $10.27 \%$ [167]. On the other hand, in an ORC electricity generation plant, replacing the VCC with ABS or ADS equipment allows cold generation by cogeneration [168]. In this sense, the results show a higher exergetic efficiency for the ORC-ADS equipment because the residual heat from the ORC feeds the ADS equipment [169]. Evaluation of the ORC-ABS configuration for cooling agricultural soil with a capacity of $3.5 \mathrm{~kW}$ and $7 \mathrm{~kW}$ allowed a payback of 9.4 years with the highest capacity [170].

ABS systems can be combined with a power generation unit (PGU) that recovers heat (HR) for domestic hot water (DHW). The electricity generated is supplied to a reversible heat pump (RHP) to produce $\mathrm{CH}$. The configuration could reduce the annual demand of a building by approximately $87 \%$ in heating, DHW, and cooling processes $[171,172]$. However, the configuration can increase investment costs because the profitability of the cogeneration system depends on the cost of heat generation fuel and local electricity. 


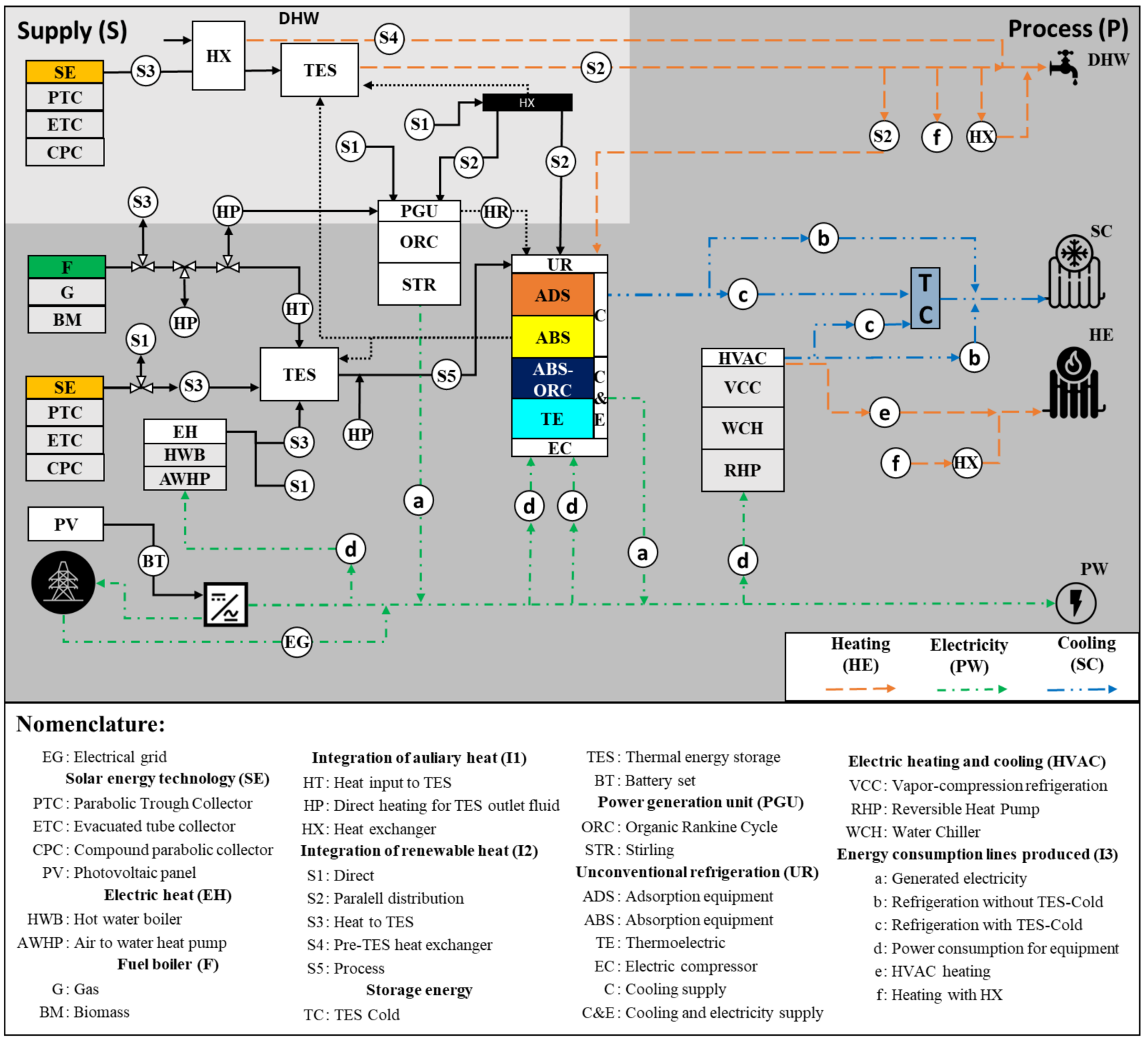

Figure 4. Integration schemes of the main cooling heat/electricity generation $(\mathrm{CH} / \mathrm{E})$ configurations described in the literature for space cooling (SC), heating (HE), domestic hot water (DHW) and electricity (PW).

Table 2. Summary of the main configurations for supply cooling-heat $(\mathrm{CH})$ and cooling-electricity $(\mathrm{CE})$.

\begin{tabular}{|c|c|c|c|c|c|c|c|c|c|c|c|c|c|}
\hline SEH & EH & F & I1 & I2 & UR & PGU & HVAC & I3 & Production & $\mathbf{P}$ & $\mathrm{S}$ & E & Reference \\
\hline PTC & & $\mathrm{BM}$ & HP & S2-S3-S4 & ABS & & & c & (DHW-HE)-SC & - & - & & [107] \\
\hline ETC & & G & $\mathrm{HP}$ & S2-S3-S4 & ABS & & & c & (DHW-HE)-SC & & - & & [108] \\
\hline ETC & & G & HP & S2-S3-S4 & ABS & & $\mathrm{WCH}$ & c & (DHW-HE)-SC & & - & & [108] \\
\hline ETC & & G & HP & S2-S3 & ABS & & $\mathrm{WCH}$ & $\mathrm{b}$ & HE-SC & & - & & [109] \\
\hline ETC & & G & HP & S2-S3 & ABS & & & $\mathrm{b}$ & HE-SC & & - & & [109] \\
\hline PV & & & & & $\mathrm{TE}$ & & & $a-b$ & SC-PW & & & - & {$[166,167]$} \\
\hline PTC & & & & S1 & ABS & ORC & & $a-b$ & SC-PW & - & & - & {$[168]$} \\
\hline & & G & HP & S2 & ADS & ORC & & $a-b$ & SC-PW & & - & - & [169] \\
\hline & & G & HP HR & S1 & ADS & ORC & & $a-b$ & SC-PW & - & & - & [169] \\
\hline ETC & & & & S1 & ABS & ORC & & $a-b$ & SC-PW & - & & - & [170] \\
\hline ETC & & G & HT & S2-S3 & ABS & & & $\mathrm{b}$ & HE-SC & & - & & [171] \\
\hline PV & AWHP & & $\mathrm{HX}$ & S1 & $\mathrm{TE}$ & & & $b-d$ & (DHW-HE)-SC & - & & - & [172] \\
\hline
\end{tabular}


Table 2. Cont.

\begin{tabular}{|c|c|c|c|c|c|c|c|c|c|c|c|c|c|}
\hline SEH & EH & F & I1 & I2 & UR & PGU & HVAC & I3 & Production & $\mathbf{P}$ & $S$ & $\mathbf{E}$ & Reference \\
\hline $\mathrm{CPC}$ & $\mathrm{EH}$ & & & S1-S3 & ABS & & VCC & $\mathrm{c}$ & (DHW-HE)-SC & & $\bullet$ & & [172] \\
\hline ETC & & & & S3-S4 & ABS & & EHP & $a-c$ & (DHW-HE)-SC & $\bullet$ & $\bullet$ & & [173] \\
\hline ETC & & $\mathrm{BM}$ & HP HX & S3-S5 & ABS & & $\mathrm{WCH}$ & $\mathrm{b}$ & DHW-SC & $\bullet$ & & & [174-176] \\
\hline ETC & & $\mathrm{BM}$ & HT HX & $\mathrm{S} 2-\mathrm{S} 4$ & ABS & & & $b-d$ & HE-SC & & $\bullet$ & & [176] \\
\hline ETC PV & & G & HT HP & S1-S3 & ABS & STR & VCC & $a-c, d$ & SC-PW & $\bullet$ & & $\bullet$ & [177] \\
\hline ETC & AWHP & G & & $\mathrm{S} 2$ & ABS & & & c & DHW-SC & $\bullet$ & & & [178] \\
\hline
\end{tabular}

The evaluations of Calise F. et al. [173] suggest eliminating the auxiliary boiler and designing the ABS to cover $20 \%$ of the demand with constant operation that, together with an electric heat pump (EHP), supplies cold to a storage tank (TC). The proposed approach saves $64.7 \%$ of primary energy with a solar fraction of $46.2 \%$ in winter and $27.7 \%$ during summer [173]. However, a multi-objective optimization considering an auxiliary heater's application shows greater energy efficiency by preheating the fluid before entering the ABS. Despite the encouraging results in energy saving, it is concluded that public financing is necessary for its profitability [108]. In this sense, Shirazi A. et al. [109] propose to include the penalty costs for $\mathrm{CO}_{2}$ production in the economic analysis. Under this approach, the optimized system achieves an annual cost balance equal to zero with savings of between 44.5 and 53.8 tons of $\mathrm{CO}_{2}$ [109]. On the other hand, by incorporating a fuel boiler with a solar field of ETC of $230 \mathrm{~m}^{2}$ for heat generation, a simple payback (SPB) of 20.3 years is achieved and a solar fraction (SF) of 0.275 [108]. In comparison, a CPC with a $500 \mathrm{~m}^{2}$ solar field and a hot water boiler (HWB) integrated with a diesel generator engine minimize the SPB to five years [174]. However, there was an increase in pollutants derived from diesel combustion. In this sense, the combining of a biomass boiler (BM) with SC-TES has the peculiarity that the burning of $\mathrm{BM}$ is considered carbon neutral. Therefore, incorporating $800 \mathrm{~m}^{2}$ of CPC makes it possible to achieve an FS of $81.8 \%$ and an SPB of 9.33 years [107]. The BM-SC-TES-ABS system was also evaluated for restaurants in China with four possible configurations that reached solar fractions between 17\% and 32\% [175]. Furthermore, preheating the fluid before entering the ABS allows energy savings of $30 \%$ in summer and $60 \%$ in winter, minimizing the use of BM $[175,176]$. The reason is that $\mathrm{BM}$ provides heat during climate variability without oversizing SC-TES systems, which is attractive when considering penalties for $\mathrm{CO}_{2}$ production from the electricity grid [174]. However, the main limitation of biomass is that it requires drying before combustion to reduce the humidity of the granules. Otherwise, it increases pollutants such as sulfur dioxide, nitrogen dioxide, and other particulate matter.

\subsection{Cooling, Heat and Electricity Generation (CHG)}

Trigeneration configurations combine electrical and mechanical drive technologies to produce cold, heat, and power generation (CHG). These systems tend to increase the solar field area because they are designed to meet the higher energy demands around electricity generation. Figure 5 shows the CHG schemes and can be interpreted from reading Table 3 . ElHelw M. et al. [179] adapted conventional cooling equipment with hot and cold coils, an enthalpy wheel and a radiant wall TEC powered by PV and SC. The study shows savings in cities such as Cairo of up to $60 \%$ of primary energy consumption compared to conventional equipment [179]. On the other hand, Buonomano A. et al. [180] evaluated the performance of a system to generate electricity, cold and heat by comparing the performance between hybrid solar collectors CPVT and PVT coupled to an ABS-SE cooler and two ADS coolers. 


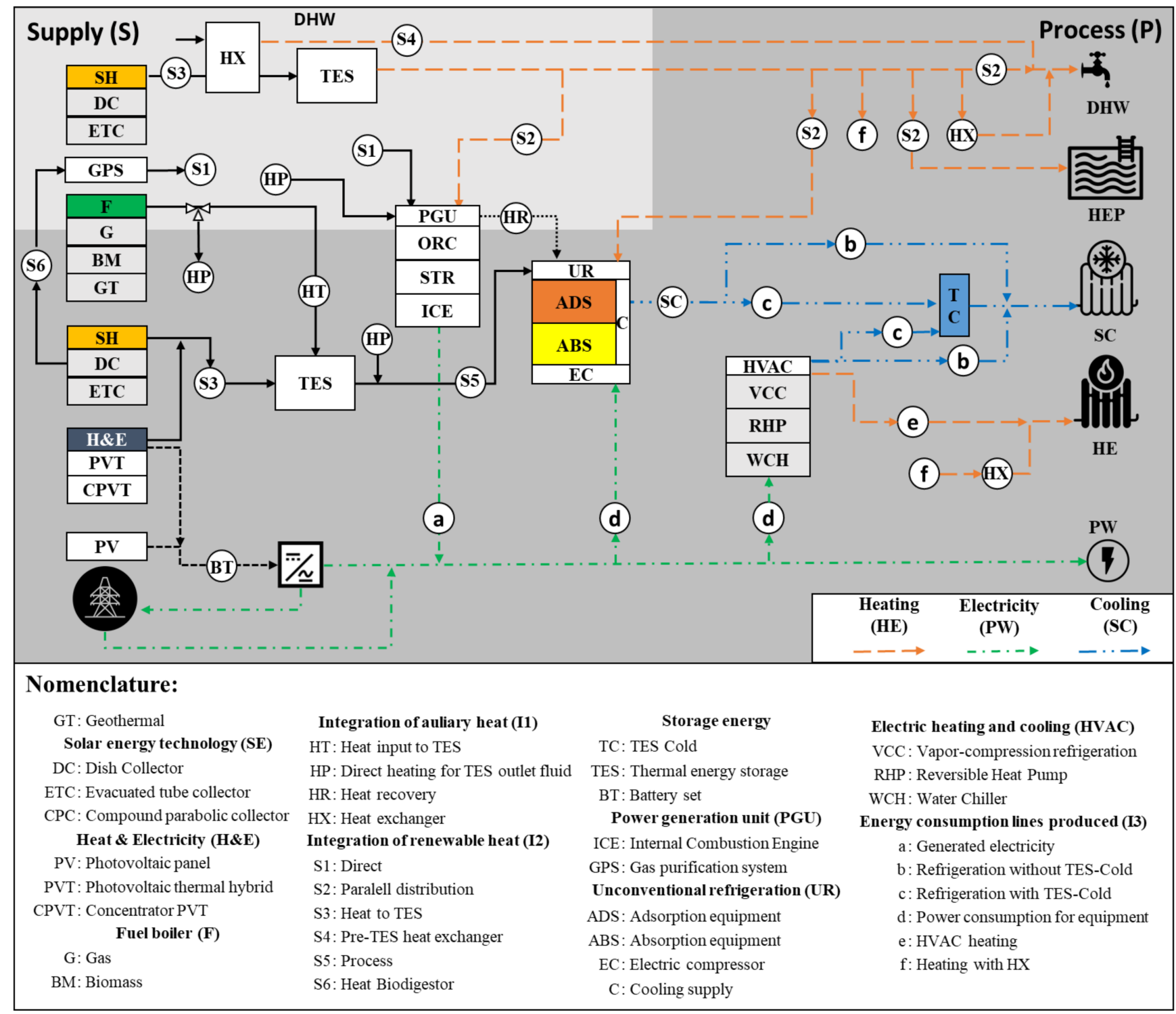

Figure 5. Integration schemes of the main cooling, heat and electricity generation (CHG) configurations described in the literature for space cooling (SC), heating (HE), domestic hot water (DHW), heating pool (HEP) and electricity (PW).

Table 3. Summary of the main configurations for supply cooling, heat and electricity (CHG).

\begin{tabular}{|c|c|c|c|c|c|c|c|c|c|c|c|c|}
\hline SEH & $\mathbf{F}$ & I1 & I2 & UR & PUG & HVAC & I3 & Production & $\mathbf{P}$ & S & $\mathbf{E}$ & Reference \\
\hline $\begin{array}{c}\text { PVT } \\
\text { CPVT }\end{array}$ & G & HP HX & S1-S2-S3-S4 & $\begin{array}{l}\text { ADS } \\
\text { ABS }\end{array}$ & & $\mathrm{WCH}$ & $c-f$ & (DHW-HEP-HE-SC-PW) & $\bullet$ & $\bullet$ & & [180] \\
\hline & G & $\mathrm{HX}$ & S2 & ABS & STR & & $b-f$ & (HE-SC-PW) & & & 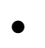 & {$[181,182]$} \\
\hline ETC PV & & HT & S2-S3 & ABS & & VCC & $c-f$ & (DHW-HE-SC-PW) & $\bullet$ & & $\bullet$ & [183] \\
\hline ETC PV & G & HT & S2-S3 & ABS & & VCC & $c-f$ & (DHW-HE-SC-SP) & $\bullet$ & & $\bullet$ & [183] \\
\hline PV & & & & & & RHP & $c-f$ & (DHW-HE-SC-PW-SP) & $\bullet$ & & $\bullet$ & [183] \\
\hline ETC PV & G-BM & HP HX & S3-S4 & ABS & ORC & & $b-f$ & (DHW-SC-PW) & $\bullet$ & & $\bullet$ & [184] \\
\hline ETC & GT & HT HP & S3-S4 & ABS & ORC & & $b-f$ & (DHW-SC-PW) & $\bullet$ & 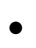 & $\bullet$ & [185] \\
\hline DC PVT & G & HR & S2-S3 & ABS & ORC & RHP & $b-e-f$ & (HE-SC-PW) & $\bullet$ & & $\bullet$ & [186] \\
\hline DC & $\begin{array}{c}\text { GPS- } \\
\text { BM }\end{array}$ & HR & S1-S2-S6 & ABS & ICE & & $b-f$ & (DHW-HE-SC-PW) & & 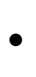 & $\bullet$ & [187] \\
\hline PVT PV & G & HT HR & S1-S2-S3 & ABS & ORC & & $\mathrm{a}-\mathrm{f}$ & (DHW-HE-SC-PW-SP) & $\bullet$ & & $\bullet$ & [188] \\
\hline
\end{tabular}


The heat generated also allows for pool water heating (HEP). The results show that the best combination of CPVT-PVT is the ABS equipment for high radiation conditions, reaching $84 \%$ of SF with an SPB of fewer than 13 years [180]. In addition, the generation of electricity with PV panels opens up the possibility of using HP as an auxiliary equipment for heat generation. However, HP systems tend to be suitable on a small scale, with the use of photovoltaic panels coupled to an RHP being even more beneficial to produce HEP, DHW, HE and SC. On the other hand, Lu, Zu. [181] developed a prototype that combines $\mathrm{ABS}$ and $\mathrm{ORC}$ equipment. The system can operate with a hot water heat source between $80-95{ }^{\circ} \mathrm{C}$ and industrial waste heat between $100-140{ }^{\circ} \mathrm{C}$ [181]. On the other hand, a PGU integrated to a gas HP as auxiliary heat was compared, achieving 38\% energy savings compared to conventional equipment. However, the configuration with a Stirling engine (STR) with ABS equipment, powered by solar thermal and photovoltaic panels, shows favorable results for the residential sector [182]. In that sense, simulations in the United States of PV-SC-ORC-ABS schemes reduced annual costs by up to $48 \%$ compared to conventional equipment [177]. The configuration SC-PVT-ABS-PUG was evaluated for harnessing the residual heat of ORC and supply heat to ABS equipment, space heating, DHW and HEP [183-185]. On the other hand, the inclusion of geothermal energy (GT) and the ability to take advantage of its annual power allows obtaining an SPB between 7.6 years and 2.5 years considering the worst and best-operating conditions, respectively [186]. On the other hand, a biomass gasifier was included replacing the solar collector system with solar dish collectors (DC). The gas drives an internal combustion generator, and the waste heat is used for heating, cooling and DHW [187].

The integration of technologies requires a technical and economic analysis to determine the optimal configuration of the system. For this reason, Sameti M. et al. [188] developed an optimization with the mixed-integer linear programming method (MILP). The objective was to determine the minimum cost of the system based on investment costs, operation, electricity and carbon emissions [188]. Furthermore, the SHC-TASK-53 project makes it possible to compare integration schemes for the residential sector in Mediterranean climatic conditions [184]. However, residential applications tend to have design differences compared to the demand for industrial applications.

\subsection{Cooling, Heat, Electricity Generation and Desalinization (CHGD)}

Although CHG systems have a high potential to be integrated into residential and industrial processes due to the generation of medium and high-temperature process heat, CHGD systems are often designed as high-capacity thermal power plants. Figure 6 and Table 4 show diagrams in which the use of ABS equipment predominates and there is the desalination of water in the condenser of ADS equipment. Multi-effect desalination plants (MED) integrated with ORC-ABS-SC-TES are attractive for desert climates, high irradiation, and lack of water. Depending on the need to be supplied, the MED polygeneration plant can be configured to produce heat and cold that contribute to the electricity generation process, the MED desalination process. Therefore, the proposed configurations can simultaneously contribute heat, refrigeration, electricity, and desalinated water (CHGD) [189]. In this sense, the schemes have been evaluated by integrating Kalina cycle absorption refrigeration and freeze desalination (CPCD) technologies. The results show that even though high evaporator temperatures produce more refrigerant, the energy and exergy efficiencies of CPCD are better under low-temperature conditions [190]. 


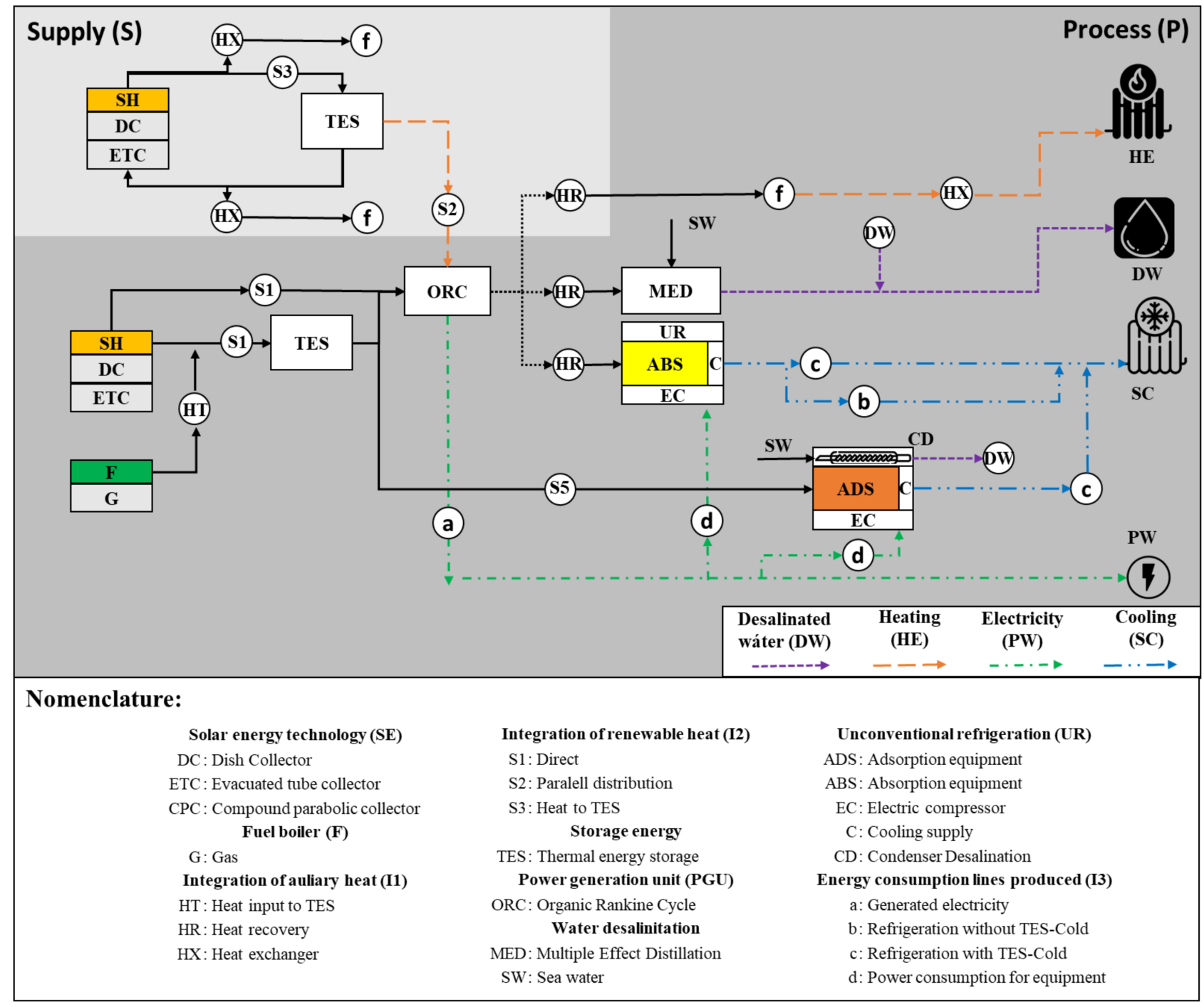

Figure 6. Integration schemes of the main cooling, heat, electricity generation and desalinization (CHGD) configurations described in the literature for space cooling (SC), heating (HE), domestic hot water (DHW), desalinated water (DW) and electricity $(\mathrm{PW})$.

Table 4. Summary of the main configurations for supply cooling, heat, desalinated water, and electricity (CHG).

\begin{tabular}{|c|c|c|c|c|c|c|c|c|c|c|c|}
\hline SEH & $\mathbf{F}$ & I1 & I2 & UR & PUG & I3 & Generation & $\mathbf{P}$ & $\mathbf{S}$ & $\mathrm{E}$ & Reference \\
\hline $\mathrm{DC}$ & & HR & S1 & ABS & ORC & $\mathrm{b}$ & (DW-SC-PW) & $\bullet$ & & $\bullet$ & {$[189,190]$} \\
\hline $\mathrm{DC}$ & G & HT HX HR & $\mathrm{S} 2, \mathrm{~S} 3$ & ABS & ORC & $\mathrm{b}$ & (DW-HE-SC-PW) & $\bullet$ & $\bullet$ & $\bullet$ & {$[191,192]$} \\
\hline ETC & & HX HR & S3 & ADS & ORC & $b-d$ & (DW-SC) & $\bullet$ & & $\bullet$ & {$[193,194]$} \\
\hline
\end{tabular}

In order to identify the techno-economic and exergetic advantages of the system, thermo-economic evaluations were recommended due to the precision to consider the exergetic destruction of the solar thermal circuit and the power block [191]. Furthermore, according to integration evaluations, the configurations with the most significant potential in high solar irradiation conditions were the plants that replace the power cycle condenser with the MED plant, and the refrigeration plant and the process heat plant were coupled to the turbine [192]. On the other hand, the production of heat, cooling, and desalination is possible from an ADS-SC-TES configuration that includes two adsorption beds. In this system, the water evaporates by the suction effect of the adsorbent. Later, the water vapor from the adsorber bed is sent to the condenser and, as the temperature drops, the desalinated water is collected in a collection tank [193,194]. The advantage of adsorption 
desalination systems is that the system has few moving parts. However, its viability in relation to size is limited by the low efficiency of the adsorption cycle. In contrast to MED-ORC configurations, the ADS-DES system does not produce electricity. Therefore, when considering annual assessments, ADS-DES could be affected by annualized costs for large-scale applications. In this sense, there is no integration analysis that evaluates the best selection criteria for industrial applications and their life cycle in terms of primary energy saving and investment. On the other hand, integration configurations are limited to heat recovery to power the MED plant and the air-conditioning equipment, minimizing the power loss of the PGU.

\section{Discussion of Potential Applications of Solar Cooling Technologies}

Solar systems require an analysis of parameters such as the levelized cost of energy (LCOE), simple pay back (SPB), and primary energy savings (PES). In addition, it is crucial to evaluate the cooling loads based on the target cooling process. This section is divided into the costs of polygeneration integrated cooling systems and the potential applications of cooling systems in the industry.

\subsection{Costs of Polygeneration Integrated Cooling Systems}

Solar cooling systems have shown that their viability is possible with schemes that supply heat and electricity simultaneously. Even the integration of polygeneration systems has shown better exergetic performance than conventional equipment, the main limitation being the efficiency and cost of the solar system. In that sense, solar systems must be evaluated based on their useful life cycle since the initial investment tends to be high due to the solar field and the cost of alternative cooling equipment. In addition, the viability of solar cooling systems varies depending on the application site and the economic factors given by local policies. An example is an ABS system in Dubai, which despite increasing the initial investment to almost $93 \%$, the SPB is 2.49 years. This is possible because the system reduces $303.68 \mathrm{tCO}_{2}$ /yr being highly beneficial due to the $\mathrm{CO}_{2}$ taxes [174]. Whereas ABS-SC configurations in Sidney reduced emissions by $166 \mathrm{tCO}_{2} / \mathrm{yr}$, but the SPB is 63 years [109]. Table 5 summarizes the costs, and key indicators of some case studies of cooling systems with energy polygeneration.

Table 5. Summary of costs and key indicators of case studies of cooling systems with energy polygeneration.

\begin{tabular}{|c|c|c|c|c|c|c|c|c|c|c|}
\hline Ref. & Sche. & App. & City & $\begin{array}{c}\text { Space } \\
{\left[\mathrm{m}^{2}\right]}\end{array}$ & $\begin{array}{l}\text { Cooling } \\
\text { Tech. }\end{array}$ & $Q_{c h}[\mathbf{k W}]$ & $\begin{array}{l}\text { Solar } \\
\text { Tech. }\end{array}$ & Area $\left[\mathrm{m}^{2}\right]$ & $\begin{array}{c}\text { Total Cost } \\
{[k €]}\end{array}$ & $\begin{array}{c}\text { Key } \\
\text { Indicators }\end{array}$ \\
\hline \multirow{3}{*}{ [108] } & \multirow{3}{*}{$\mathrm{CH} / \mathrm{E}$} & \multirow{3}{*}{$\begin{array}{c}\text { Office } \\
\text { Building }\end{array}$} & \multirow{3}{*}{ Naples } & \multirow{2}{*}{$\begin{array}{l}1600 \\
1600\end{array}$} & ABS-SE & - & ETC & 230 & 470.28 & $\begin{array}{c}\eta_{\mathrm{G}}: 0.27 \\
\text { PES: } 0.444 \\
\text { SPB: } 31.3 \mathrm{yr} \\
\text { SF: } 0.876\end{array}$ \\
\hline & & & & & ABS-SE & - & ETC & 100 & 656.56 & $\begin{array}{c}\eta_{\mathrm{G}}: 0.263 \\
\text { PES: } 0.408 \\
\text { SPB: } 32.3 \mathrm{yr} \\
\text { SF: } 0.885\end{array}$ \\
\hline & & & & 6400 & ABS-SE & - & ETC & 230 & 442.79 & $\begin{array}{c}\eta_{\mathrm{G}}: 0.268 \\
\text { PES: } 0.424 \\
\text { SPB: } 25.2 \mathrm{yr} \\
\text { SF: } 0.882\end{array}$ \\
\hline [109] & $\mathrm{CH} / \mathrm{E}$ & Hotel & Sydney & 11,624 & ABS-SE & 1023 & PTC & 3.134 & 589.96 & $\begin{array}{c}\eta_{\mathrm{G}}: 0.7 \\
\text { PES: } 0.60 \\
\text { ER: } 138 \mathrm{tCO}_{2} / \mathrm{yr} ; \\
\text { SPB: } 58.444 \mathrm{yr} \\
\text { SF: } 0.63\end{array}$ \\
\hline [109] & $\mathrm{CH} / \mathrm{E}$ & Hotel & Sydney & 11,624 & ABS-DE & 1163 & PTC & 3.278 & 611.83 & $\begin{array}{c}\eta_{\mathrm{G}}: 1.31 \\
\text { PES: } 0.65 \\
\text { ER: } 153.85 \mathrm{tCO}_{2} / \mathrm{yr} \\
\text { SPB: } 52.017 \mathrm{yr} \\
\text { SF: } 0.74\end{array}$ \\
\hline
\end{tabular}


Table 5. Cont.

\begin{tabular}{|c|c|c|c|c|c|c|c|c|c|c|}
\hline Ref. & Sche. & App. & City & $\begin{array}{c}\text { Space } \\
{\left[\mathrm{m}^{2}\right]}\end{array}$ & $\begin{array}{l}\text { Cooling } \\
\text { Tech. }\end{array}$ & $Q_{c h}[\mathrm{~kW}]$ & $\begin{array}{l}\text { Solar } \\
\text { Tech. }\end{array}$ & $\begin{array}{l}\text { Area } \\
{\left[\mathrm{m}^{2}\right]}\end{array}$ & $\begin{array}{c}\text { Total Cost } \\
{[\mathbf{k} €]}\end{array}$ & $\begin{array}{c}\text { Key } \\
\text { Indicators }\end{array}$ \\
\hline [109] & $\mathrm{CH} / \mathrm{E}$ & Hotel & Sydney & 11,624 & ABS-TE & 1163 & PTC & 3.426 .2 & 640.54 & $\begin{array}{c}\eta_{\mathrm{G}}: 1.62 \\
\text { PES: } 0.69 \\
\text { ER: } 166.43 \mathrm{tCO}_{2} / \mathrm{yr} ; \\
\text { SPB: } 63.82 \mathrm{yr} \\
\text { SF: } 0.72\end{array}$ \\
\hline [107] & $\mathrm{CH} / \mathrm{E}$ & $\begin{array}{l}\text { School } \\
\text { cooling }\end{array}$ & Marseille & - & ABS-DE & 250 & PTC & 800 & - & $\begin{array}{c}\text { PES: } 0.956 S P B: 13.7 \\
\text { yrSF: } 0.966\end{array}$ \\
\hline \multirow{3}{*}{ [109] } & \multirow{3}{*}{$\mathrm{CH} / \mathrm{E}$} & \multirow{3}{*}{ Office } & \multirow{3}{*}{ Sydney } & 11,624 & ABS-SE & 1023 & PTC & 1.986 & 454.60 & $\begin{array}{c}\eta_{\mathrm{G}}: 0.68 \\
\text { PES: } 0.39 \\
\text { ER: } 72.64 \mathrm{t} \mathrm{CO}_{2} / \mathrm{yr} \\
\text { SPB: } 63.14 \mathrm{yr} \\
\text { SF: } 0.69\end{array}$ \\
\hline & & & & 11,624 & ABS-DE & 1163 & PTC & 1.885 & 471.69 & $\begin{array}{c}\eta_{\mathrm{G}}: 1.31 \mathrm{PES}: 0.31 \text { ER: } \\
\text { 81.58tCO } \mathrm{tCO}_{2} / \mathrm{yrSPB}: \\
58.17 \text { yrSF: } 0.76\end{array}$ \\
\hline & & & & 11,624 & ABS-TE & 1163 & PTC & 1.912 & 485.36 & $\begin{array}{c}\eta_{\mathrm{G}}: 1.61 \\
\text { PES: } 0.37 \\
\text { SF: } 0.75 \\
\text { ER: } 97.80 \mathrm{tCO}_{2} / \mathrm{yr} \\
\text { SPB: } 71.19\end{array}$ \\
\hline [160] & $\mathrm{CH} / \mathrm{E}$ & $\begin{array}{l}\text { District } \\
\text { cooling }\end{array}$ & Qatar & - & ABS & 12,000 & FPC & 5.342 .2 & 1.746 .96 & - \\
\hline [170] & $\mathrm{CH} / \mathrm{E}$ & $\begin{array}{l}\text { Soil } \\
\text { cooling } \\
\text { (Alstroe- } \\
\text { meria) }\end{array}$ & $\begin{array}{l}\text { Kuala } \\
\text { Lumpur }\end{array}$ & - & ABS-SE & 3.5 & ETC & 22 & 12.44 & $\begin{array}{c}\text { ER: } 4.5 \mathrm{tCO}^{2} \\
\text { Annual Savings: } \\
977.57 € \\
\text { SPB: } 14.2 \mathrm{yr}\end{array}$ \\
\hline [170] & $\mathrm{CH} / \mathrm{E}$ & $\begin{array}{l}\text { Soil } \\
\text { cooling } \\
\text { (Alstroe- } \\
\text { meria) }\end{array}$ & $\begin{array}{l}\text { Kuala } \\
\text { Lumpur }\end{array}$ & - & ABS-SE & 7 & ETC & 44 & 19.13 & $\begin{array}{c}\text { ER: } 32 \mathrm{tCO}_{2} \\
\text { Annual Savings: } \\
1880.11 € \\
\text { SPB: } 10.8\end{array}$ \\
\hline \multirow{7}{*}{ [172] } & \multirow{7}{*}{$\mathrm{CH} / \mathrm{E}$} & \multirow{7}{*}{$\begin{array}{l}\text { Heating } \\
\text { and } \\
\text { cooling } \\
\text { space }\end{array}$} & \multirow{7}{*}{$\begin{array}{c}\text { Abu } \\
\text { Dhabi, } \\
\text { Kjakarta, } \\
\text { Amman, } \\
\text { Milan, } \\
\text { New York }\end{array}$} & 1246 & RHP & 160 & $\mathrm{CPC}$ & 500 & 165.53 & LCOE: $0.122 € / \mathrm{kWh}$ \\
\hline & & & & 1246 & RHP & 160 & PV & 497 & 211.37 & LCOE: $0.0939 € / \mathrm{kWh}$ \\
\hline & & & & 1246 & VCC & 160 & - & - & 170.17 & LCOE: $0.0921 € / \mathrm{kWh}$ \\
\hline & & & & 1246 & RHP & 160 & - & - & 120.49 & LCOE: $0.1029 € / \mathrm{kWh}$ \\
\hline & & & & 1246 & RHP & 160 & - & - & 487.92 & LCOE: $0.0994 € / \mathrm{kWh}$ \\
\hline & & & & 1246 & $\begin{array}{l}\text { VCC+ } \\
\text { ABS }\end{array}$ & 160 & $\mathrm{CPC}$ & 500 & 274.45 & LCOE: $0.0784 € / \mathrm{kWh}$ \\
\hline & & & & 1246 & RHP & 160 & PV & & 297.23 & LCOE: $0.0355 € / \mathrm{kWh}$ \\
\hline \multirow{3}{*}{ [173] } & \multirow{3}{*}{$\mathrm{CH} / \mathrm{E}$} & \multirow{3}{*}{$\begin{array}{l}\text { School } \\
\text { cooling }\end{array}$} & Naples & 2250 & ABS-SE & 300 & PTC & 200 & - & $\begin{array}{l}\eta_{G}: 0.458 \\
\text { PES: } 0.647 \\
\text { SPB: } 19 \mathrm{yr} \\
\text { SF: } 0.462 \\
\eta_{C}: 0.433\end{array}$ \\
\hline & & & Milan & 2250 & ABS-SE & 300 & PTC & 200 & - & $\begin{array}{l}\text { PES: } 0.524 \\
\text { SPB: } 31.4 \mathrm{yr} \\
\text { SF: } 0.325\end{array}$ \\
\hline & & & Trapani & 2250 & ABS-SE & 300 & PTC & 200 & - & $\begin{array}{c}\eta_{G}: 0.461 \\
\text { PES: } 0.614 \\
\text { SPB: } 18.9 \mathrm{yr} \\
\text { SF: } 0.263\end{array}$ \\
\hline \multirow{3}{*}{ [174] } & \multirow{3}{*}{$\mathrm{CH} / \mathrm{E}$} & \multirow{3}{*}{$\begin{array}{l}\text { Residential } \\
\text { Building }\end{array}$} & \multirow{3}{*}{ Dubai } & 400 & $\begin{array}{l}\text { ABS-DE- } \\
\text { Air } \\
\text { cooled }\end{array}$ & 109.8 & PTC & 290.9 & 1381.1 & $\begin{array}{c}\text { ER: } 303.68+\mathrm{CO}_{2} / \mathrm{yr} \\
\text { SPB: } 2.49 \mathrm{yr} \\
\text { Energy savings: } \\
519 \mathrm{MWh} / \mathrm{yr}\end{array}$ \\
\hline & & & & 400 & $\begin{array}{l}\text { ABS-DE- } \\
\text { Air } \\
\text { cooled }\end{array}$ & 76 & PTC & 193.9 & 1025.3 & $\begin{array}{c}\text { ER: } 139.7 \text { t } \mathrm{CO}_{2} / \mathrm{yr} \\
\text { SPB: } 4.75 \mathrm{yr} \\
\text { Energy savings: } \\
175.64 \mathrm{MWh} / \mathrm{hr}\end{array}$ \\
\hline & & & & 400 & $\begin{array}{c}\text { Air } \\
\text { cooled }\end{array}$ & 366 & - & - & 713.3 & - \\
\hline
\end{tabular}


Table 5. Cont.

\begin{tabular}{|c|c|c|c|c|c|c|c|c|c|c|}
\hline Ref. & Sche. & App. & City & $\begin{array}{c}\text { Space } \\
{\left[\mathrm{m}^{2}\right]}\end{array}$ & $\begin{array}{l}\text { Cooling } \\
\text { Tech. }\end{array}$ & $Q_{c h}[\mathrm{~kW}]$ & $\begin{array}{l}\text { Solar } \\
\text { Tech. }\end{array}$ & $\begin{array}{l}\text { Area } \\
{\left[\mathrm{m}^{2}\right]}\end{array}$ & $\begin{array}{c}\text { Total Cost } \\
{[\mathbf{k} €]}\end{array}$ & $\begin{array}{c}\text { Key } \\
\text { Indicators }\end{array}$ \\
\hline \multirow{5}{*}{ [175] } & \multirow{5}{*}{$\mathrm{CH} / \mathrm{E}$} & \multirow{5}{*}{$\begin{array}{l}\text { Ecological } \\
\text { Restau- } \\
\text { rant }\end{array}$} & Jinan & - & ABS-SE & - & PTC & 1538 & - & SF: 0.27 \\
\hline & & & Loudi & - & ABS-SE & - & PTC & 1538 & - & SF: 0.25 \\
\hline & & & Yinchuan & - & ABS-SE & - & PTC & 1538 & - & SF: 0.28 \\
\hline & & & Lhasa & - & ABS-SE & - & PTC & 1538 & - & SF: 0.32 \\
\hline & & & Hyderabad & - & ABS-SE & - & PTC & 1538 & - & SF: 0.24 \\
\hline \multirow{4}{*}{ [176] } & \multirow{4}{*}{$\mathrm{CH} / \mathrm{E}$} & \multirow{4}{*}{$\begin{array}{l}\text { Wine } \\
\text { industry }\end{array}$} & \multirow{4}{*}{ Curicó } & - & ABS-SE & 200 & FPC & 250 & 329.99 & $\begin{array}{c}\text { Annual Savings: } \\
\text { 29,758.62 €SPB: } 10\end{array}$ \\
\hline & & & & - & ABS-SE & 200 & FPC & 500 & 379.11 & $\begin{array}{l}\text { Annual Savings: } \\
\text { 29,991.24 €SPB: } 12\end{array}$ \\
\hline & & & & - & ABS-SE & 200 & FPC & 750 & 428.23 & $\begin{array}{l}\text { Annual Savings: } \\
\text { 30,390.68 €SPB: } 14\end{array}$ \\
\hline & & & & - & ABS-SE & 200 & FPC & 1000 & 477.35 & $\begin{array}{c}\text { Annual Savings: } \\
\text { 30,935.62 € } \\
\text { SPB: } 15\end{array}$ \\
\hline [178] & $\mathrm{CH} / \mathrm{E}$ & $\begin{array}{l}\text { Space } \\
\text { cooling } \\
\text { building }\end{array}$ & Cagliari & 2460 & ABS-SE & 70 & ETC & 230 & 300 to 400 & $\eta_{G}: 0.84$ to 0.87 \\
\hline & & & San & 46,320 & ABS-SE & 530 & - & - & 836.66 & - \\
\hline [177] & $\mathrm{CHG}$ & Building & Francisco & 46,320 & ABS-SE & 700 & - & - & 788.99 & - \\
\hline & & & $\begin{array}{l}\text { Boston } \\
\text { Miami }\end{array}$ & 46,320 & ABS-SE & 830 & - & - & 1090.5 & - \\
\hline [185] & $\mathrm{CHG}$ & $\begin{array}{c}\text { Hotel } \\
\text { Building }\end{array}$ & Changsha & - & ABS & - & - & - & - & Cost Savings: $31.59 \%$ \\
\hline [186] & $\mathrm{CHG}$ & $\begin{array}{l}\text { Hotel } \\
\text { Building }\end{array}$ & Ischia & - & ABS-SE & 30 & ETC & $25-80$ & 91.24 & $\begin{array}{l}\text { SPB: } 7.6 \\
\eta_{\mathrm{G}}: 0.592\end{array}$ \\
\hline & & & Cairo & 25,8129 & $\begin{array}{l}\text { TEC-Cell } \\
\text { Enthalpy } \\
\text { Wheel }\end{array}$ & - & PVSP & - & 26.49 & $\begin{array}{l}\text { Annual Savings: } \\
\quad 2613.82 €\end{array}$ \\
\hline [179] & $\mathrm{CHG}$ & Building & Alexandria & 25,8129 & $\begin{array}{l}\text { TEC-Cell } \\
\text { Enthalpy } \\
\text { Wheel }\end{array}$ & - & PVSP & - & 26.49 & $\begin{array}{l}\text { Annual Savings: } \\
\quad 3162.24 €\end{array}$ \\
\hline & & & Hurghada & 25,8129 & $\begin{array}{l}\text { TEC-Cell } \\
\text { Enthalpy } \\
\text { Wheel }\end{array}$ & - & PVSP & - & 26.49 & $\begin{array}{l}\text { Annual Savings: } \\
\quad 2019.61 €\end{array}$ \\
\hline & & & & & & & & & & $\begin{array}{c}\text { Annual Savings: } \\
1710.21 €\end{array}$ \\
\hline & & & Berlin & - & ABS-ADS & 258.7 & CPVT & 2,069 & 1005.5 & $\begin{array}{c}\text { SPB: } 12.5 \text { yr } \\
\text { SF: } 0.82 \\
\text { Energy savings: } \\
\text { 1839 MWh/yr } \\
\text { Annual Savings: }\end{array}$ \\
\hline [180] & $\mathrm{CHG}$ & $\begin{array}{l}\text { Office } \\
\text { Building }\end{array}$ & Bordeaux & - & ABS-ADS & 237 & CPVT & 1896 & 822.06 & $\begin{array}{c}\text { 1979.26 €SPB: 10.3SF: } \\
\text { 0.63 Energy savings: } \\
2126 \mathrm{MWh} / \mathrm{yr}\end{array}$ \\
\hline & & & & & & & & & & $\begin{array}{l}\text { Annual Savings: } \\
3778.85 €\end{array}$ \\
\hline & & & Athens & - & ABS-ADS & 325.6 & CPVT & 2821 & 1875.9 & $\begin{array}{l}\text { SPB: 16.7SF: } 0.78 \\
\text { Energy savings: } \\
\text { 4059 MWh/yr }\end{array}$ \\
\hline [188] & CHG & $\begin{array}{l}\text { District } \\
\text { cooling }\end{array}$ & Risch-Rotkreuz & 8500 & AD-ABS & 1517.6 & PTC & $50-76$ & $67.50 \mathrm{k} € / \mathrm{yr}$ & - \\
\hline
\end{tabular}

On the other hand, $\mathrm{PV}, \mathrm{SC}$, and conventional renewable energy prices are described widely in the literature. However, even though solar collectors have lowered costs in the last two decades, thermal cooling systems have made modest progress in reducing costs. Cooling systems reduce the cost per $\mathrm{kW}$ as a function of increasing the nominal capacity (NC) of the equipment. Table 6 shows the main functions (F) considered in the literature to estimate the specific cost of refrigeration equipment according to NC. F1 was obtained from Broad Air Conditioning Ltd. Suppliers, while F2 was performed under a polynomial relationship developed by Waier P. in 2008 [157]. 
Table 6. Thermally powered refrigeration equipment cost estimating functions.

\begin{tabular}{cccccc}
\hline $\mathbf{N}^{\circ}$ & Equipment & Type & Cost Functions & Unit & Ref. \\
\hline F1 & ABS & DE (small size) & $500 \times \mathrm{NC}$ & USD & {$[157]$} \\
F2 & ABS & DE (large size) & $147.3 \times \mathrm{NC}+100,680$ & USD & {$[157]$} \\
F3 & ABS & SE & $585 \times \mathrm{NC}$ & AUD & {$[109]$} \\
F4 & ABS & DE & $705 \times \mathrm{NC}$ & AUD & {$[109]$} \\
F5 & ABS & TE & $855 \times \mathrm{NC}$ & AUD & {$[109]$} \\
F6 & ADS & High temperature & $500 \times \mathrm{NC}$ & $€$ & {$[180]$} \\
F7 & ADS & Low temperature & $400 \times \mathrm{NC}$ & $€$ & {$[180]$} \\
F8 & ABS & - & $300 \times \mathrm{NC}$ & $€$ & {$[180]$} \\
F9 & ADS & - & $1680 \times \mathrm{NC}^{-0,17}$ & $€ / \mathrm{kW}$ & {$[184]$} \\
F10 & ABS & SE & $3700 \times \mathrm{NC}^{-0,45}$ & $€ / \mathrm{kW}$ & {$[184]$} \\
F11 & ABS & DE & $4300 \times \mathrm{NC}^{-0,45}$ & $€ / \mathrm{kW}$ & {$[184]$} \\
\hline
\end{tabular}

The values determined by Shirazi A. et al. [109] for F3, F4 and F5 were estimated from supplier data obtained between 2012 and 2014. On the other hand, F6, F7, and F8 were based on estimates referring to 2016 [180]. While F8, F9, and F10 are approximation functions obtained from the Task-53 project, based on 2012 data from Central Europe [184]. Thermal cooling equipment costs change depending on the manufacturer, year of production, equipment type, capacity, COP, transportation, taxes, etc. Regarding the technical aspects, it is expected that $\mathrm{ABS}$ equipment increases as a function of COP. However, the functions detailed in Table 6 are estimates based on the capacity and type of equipment, leaving out several technical and economic parameters that directly influence the final costs.

In this sense, Figure 7 shows the reported nominal capacity versus the specific prices per $\mathrm{kW}$ of cooling, and Figure 8 shows the relationship between specific cost, COP and equipment capacity. The values reported are studies described in this document and compared with the estimated values described by Hang Y. et al. [157] and Neyer D. et al. [184] for ABS-SE ABS-DE equipment transforming into Euros using the exchange closing rate as of 31 December 2020, for USD, AUD, AED, and MYR. The figures show a clear difference between the cost functions assumed and the costs reported by other authors. Consequently, using the reported functions to determine costs without adapting to the local market could limit the precision of a techno-economic analysis.

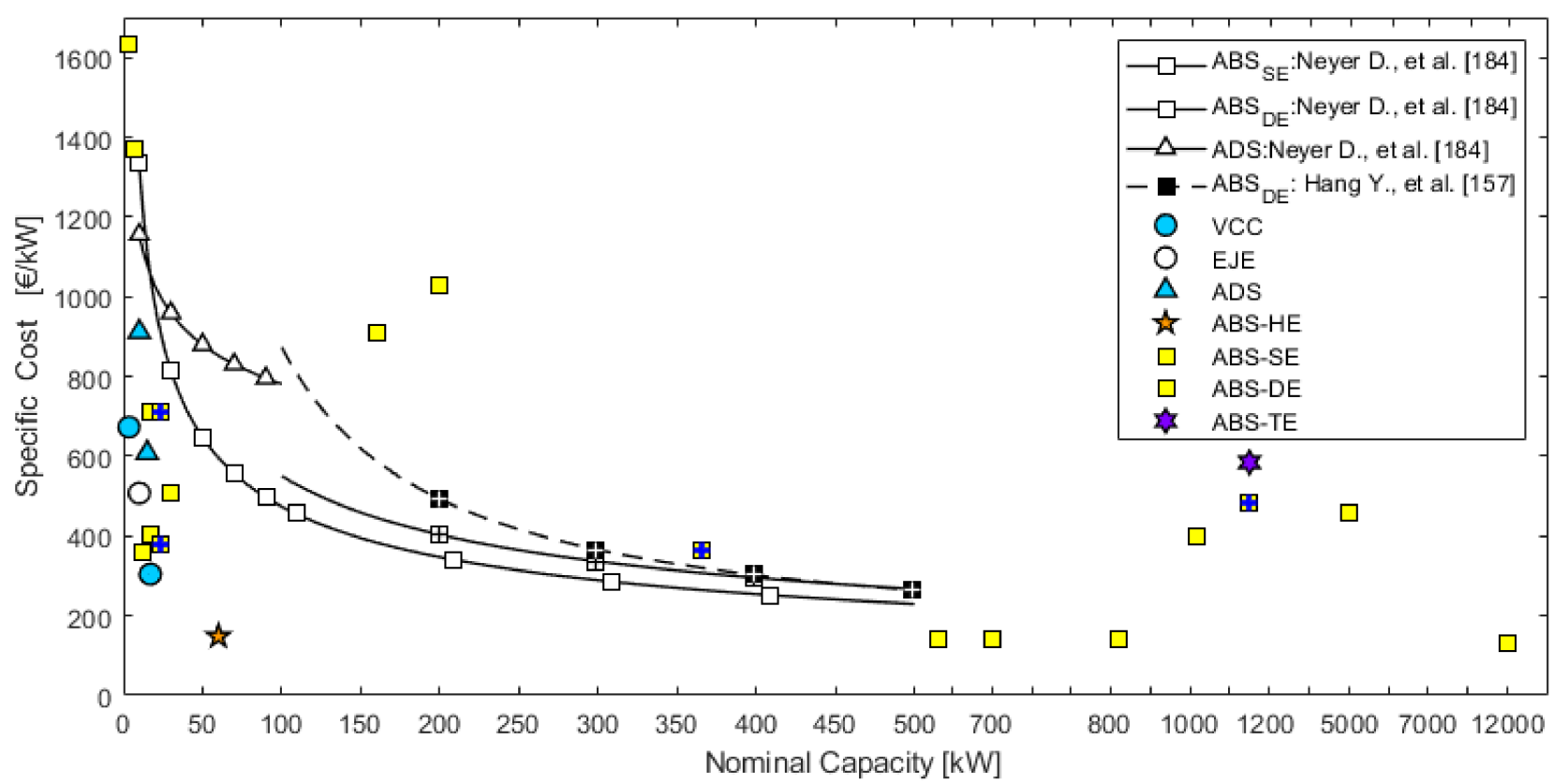

Figure 7. Comparison of heat-driven refrigeration equipment based on nominal capacity versus specific costs reported in the literature. Own figure based on [184]. 


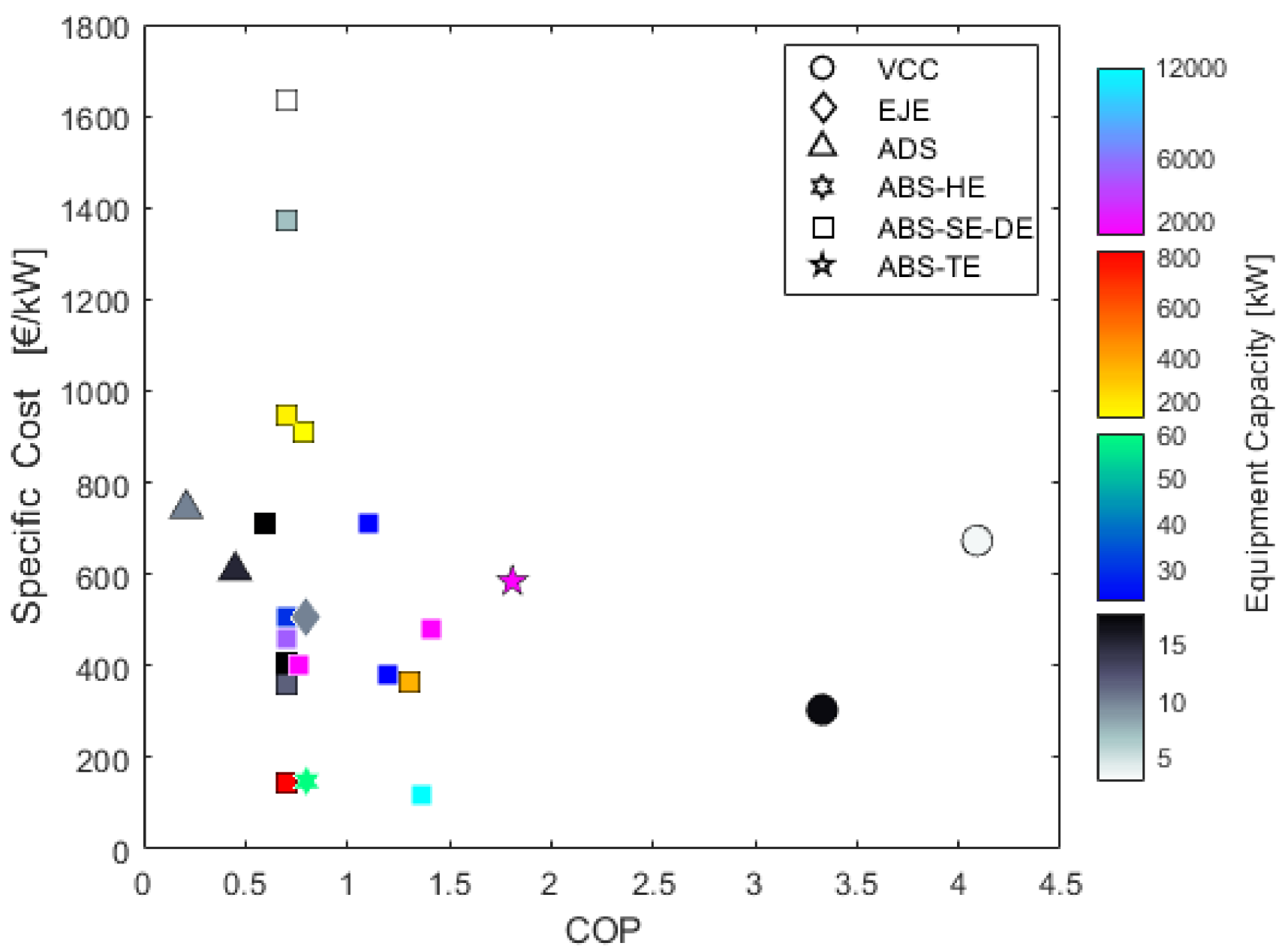

Figure 8. Comparison of heat-driven refrigeration equipment based on COP versus specific costs reported in the literature.

\subsection{Potential Applications of Cooling Systems in the Industry}

The adaptations of PV panels with HR or VCC equipment for air-conditioning and $\mathrm{CH} / \mathrm{E}$ schemes are most commonly found in the residential sector. The challenges of residential air conditioning are based on reaching the comfort temperature, which is standardized according to the ASHRAE standards and adapted according to each country's local legislation. District refrigeration systems have also been evaluated to supply heat and cold, requiring them to cover cooling loads of $12 \mathrm{MW}$ [160]. However, evaluations for industrial applications have hardly been evaluated, limiting themselves to the agricultural sector for soil cooling for alstroemeria cultivar with temperature control in greenhouses [170]. The temperature control requirements for the above processes require $T_{\text {set }}>3{ }^{\circ} \mathrm{C}$. The cold storage of fruit, pre-cooling, and cooling pork meat after cutting has been evaluated [151,152]. Based on the review developed in this document, Figure 9 shows location maps of solar cooling plants in which residential sector applications predominate.

Solar cooling systems have potential because the industry requires controlling the temperature for manufacturing processes, and the economic viability of solar thermal systems tends to be improved in polygeneration schemes. In this sense, the fruit and vegetable industry require reducing the temperature from $23^{\circ} \mathrm{C}$ to $-1{ }^{\circ} \mathrm{C}$. Cooling time is essential to avoid deformations in vegetables such as cabbage and spinach. On the other hand, the storage of meat derivatives requires set temperatures of the evaporator equipment that can reach up to $-35{ }^{\circ} \mathrm{C}$, being unfeasible for sorption equipment. In this sense, studies suggest evaluating processes derived from canned foods. The process requires cooling from $70{ }^{\circ} \mathrm{C}$ to $4{ }^{\circ} \mathrm{C}$ but must occur between 565 and $855 \mathrm{~min}$ to prevent microorganism growth [196]. 


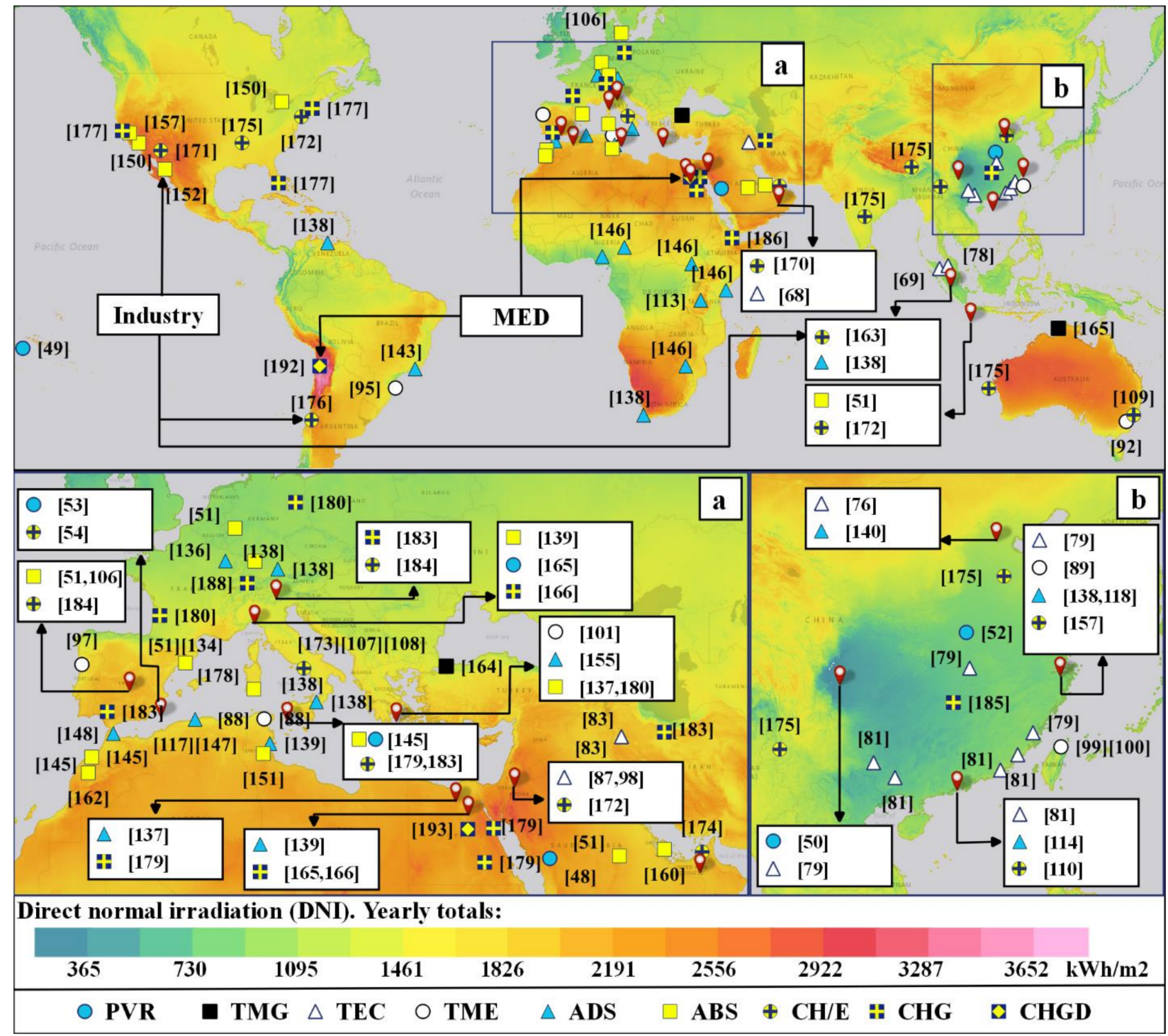

Figure 9. Location of solar cooling plants described in Sections 2 and 3. (a) Europe and the Middle East. (b) Southeast Asia. Own figure based on [195]: Yearly DNI.

Table 7. Operating parameters of cooling processes applied in the food industry.

\begin{tabular}{|c|c|c|c|c|c|c|}
\hline Ref. & Process & Product & $\begin{array}{c}\text { Initial T } \\
{\left[{ }^{\circ} \mathrm{C}\right]}\end{array}$ & Final $\mathrm{T}\left[{ }^{\circ} \mathrm{C}\right]$ & $Q_{e x t}[\mathrm{kWh}]$ & $\begin{array}{l}\text { Cooling Time } \\
\text { [min] }\end{array}$ \\
\hline [196] & Forced-air cooling & Cabbage, spinach & 23 & -1 & 1.13 & 188 \\
\hline [196] & High flow hydrocooling & Cabbage, spinach & 23 & -1 & 0.67 & 64 \\
\hline [196] & Low flow hydrocooling & Cabbage, spinach & 23 & -1 & 0.78 & 84 \\
\hline [196] & Air blast cooling & Cooked pork & 70 & 4 & - & 565 \\
\hline [196] & Water immersion cooling & Cooked pork & 70 & 4 & - & 855 \\
\hline [197] & Cooling on crystallization & Shortening production & 60 & 12 & - & 100 \\
\hline [197] & Cooling on crystallization & Shortening production & 60 & 12 & - & 100 \\
\hline
\end{tabular}

In addition, chemical processes such as crystallization are required in the food industry, which is part of the reduction of production [197]. The cooling on crystallization is also present in other manufacturing processes in the chemical industry. Table 7 summarizes the food industry processes with the potential to be evaluated with solar cooling systems.

Supermarket applications require cooling demands of more than $100 \mathrm{~kW}$, comparable to medium-scale winemaking processes. However, the advantage in winemaking processes 
is the possibility to take advantage of the heat of the solar field, even when the sorption chiller is not in operation [176]. Solar systems have only been evaluated on a small scale for fermentation processes and storage in white wine warehouses.

On the other hand, mining applications require strict control of the cooling temperature to guarantee the thermal comfort of the workers. The temperature should be kept below $28{ }^{\circ} \mathrm{C}$, but activities stop if it exceeds $32{ }^{\circ} \mathrm{C}$ [198]. Refrigeration loads will vary depending on the location, depth, number of workers, machinery, etc. A mine's cooling system can be centralized on the surface or underground.

Therefore, mine cooling systems can be classified as icy refrigeration, cooled air stream, ventilation cooled air stream, etc. In that sense, to obtain an optimal result, it is important to consider the disposition of the equipment in the mine. According to some authors, coal mines require equipment between $4 \mathrm{MW}$ and $16.3 \mathrm{MW}$ and gold mines between $0.8 \mathrm{MW}$ and $39 \mathrm{MW}$, as shown in Table 8. Although absorption systems have been evaluated with cooling equipment of $12 \mathrm{MW}$, the systems have not been evaluated for mining applications.

Table 8. Thermally powered refrigeration equipment cost estimating functions.

\begin{tabular}{|c|c|c|c|c|c|c|c|}
\hline Ref. & Country & Apply & Process & $T_{\text {process }}\left[{ }^{\circ} \mathrm{C}\right]$ & $T_{\text {set }}\left[^{\circ} \mathrm{C}\right]$ & Cooling System & NC [kW] \\
\hline [198] & England & Supermarket & Supermarket & $\begin{array}{l}\text { Comfort } \\
\text { Temp. }\end{array}$ & - & Air-cooled system & $125-400$ \\
\hline [198] & England & Supermarket & Supermarket & $\begin{array}{l}\text { Comfort } \\
\text { Temp. }\end{array}$ & - & Water-cooled system & $130-180$ \\
\hline [198] & England & Supermarket & Supermarket & $\begin{array}{l}\text { Comfort } \\
\text { Temp. }\end{array}$ & - & Hybrid system & 125-180 \\
\hline [199] & Italy & Winemaking & Barrel cellar & $15-16$ & 2 & Air-cooled water chiller & 458 \\
\hline [199] & Italy & Winemaking & $\begin{array}{l}\text { Wine Storage } \\
\text { warehouses }\end{array}$ & $20-21$ & 2 & Air-cooled water chiller & 458 \\
\hline [199] & Italy & Winemaking & Alcoholic fermentation & 18 & 2 & Air-cooled water chiller & 458 \\
\hline [199] & Italy & Winemaking & Malolactic fermentation & 17 & 2 & Air-cooled water chiller & 458 \\
\hline [199] & Italy & Winemaking & $\begin{array}{l}\text { Cold (static) } \\
\text { stabilization } \\
\text { pre-filtration }\end{array}$ & -4 & -7 & $\begin{array}{l}\text { Air-cooled water chiller } \\
\text { with heat recovery }\end{array}$ & 466 \\
\hline [199] & Italy & Winemaking & $\begin{array}{l}\text { Cold (static) } \\
\text { stabilization cold new } \\
\text { wine }\end{array}$ & 2 & -7 & $\begin{array}{l}\text { Air-cooled water chiller } \\
\text { with heat recovery }\end{array}$ & 466 \\
\hline [199] & Italy & Winemaking & Wine dynamic cooler & & -4 & $\begin{array}{l}\text { Air-cooled direct } \\
\text { expansion cooler }\end{array}$ & 197.6 \\
\hline [200] & China & Mine & Coal & $<30$ & 18 & Icy refrigeration & 6250 \\
\hline [200] & China & Mine & Coal & $<30$ & 18 & Icy cooling system & 12,000 \\
\hline [200] & China & Mine & Coal & $<30$ & 18 & $\begin{array}{l}\text { Centralized refrigeration } \\
\text { system on the surface }\end{array}$ & 10,000 \\
\hline [200] & China & Mine & Coal & $<30$ & 18 & $\begin{array}{l}\text { Centralized refrigeration } \\
\text { system underground }\end{array}$ & 6250 \\
\hline [201] & Australia & Mine & Coal & 22 & - & Cooled air stream & 4000 \\
\hline [202] & China & Mine & Coal & $30-32$ & 7.03 & $\begin{array}{l}\text { Ventilation and cooling } \\
\text { system }\end{array}$ & 16,250 \\
\hline [203] & South Africa & Mine & Gold & $<27.5$ & & Refrigeration plant & $\begin{array}{l}3000 \text { to } \\
16,400\end{array}$ \\
\hline [203] & South Africa & Mine & Gold & $<27.5$ & - & $\begin{array}{l}\text { Variable speed drive } \\
\text { (VSD) }\end{array}$ & 816 \\
\hline [204] & South Africa & Mine & Gold & $<27.5$ & $3-9$ & Refrigeration plant & 39,000 \\
\hline
\end{tabular}

\section{Conclusions}

Achieving the decarbonization of electricity in 2050 requires reducing electricity consumption growth, and cooling processes are responsible for $10 \%$ of such consumption. The investigations have been oriented to using renewable energies with alternative equipment 
integrated with thermal or PV panels. However, there is a marked imbalance in the number of studies in the residential sector, despite the potential benefits of reducing electricity and $\mathrm{CO}_{2}$ with renewable energies This present work details polygeneration schemes focusing on solar refrigeration and the potential application in the industry. In this sense, the review presented the unconventional refrigeration equipment, polygeneration schemes, and scope of applicability in industry.

- $\quad$ Alternative solar cooling technologies have energy limitations due to their low COP and limiting their overall efficiency. However, the hybridization of cooling devices to reduce heat transfer losses allows the COP to be maximized. In this sense, STR and TEC devices combined with conventional refrigeration equipment and facades must be evaluated to determine their viability.

- $\quad$ PV-VCC or PV-HPR configurations outperform typical SC-TES systems and thermal cooling equipment schemes due to the economic viability and SPB of fewer than 10 years. The reason is that conventional refrigeration equipment is preserved, and excess electricity production is used by other equipment connected to the electrical network. However, the economic viability of photovoltaic systems must be evaluated considering simultaneous heat and cold thermal loads to determine the sizing limits of PVR systems in industrial applications.

- $\quad$ The literature presented confirms that the viability of alternative equipment depends on its adaptation to polygeneration schemes that allow $\mathrm{CE}$ and $\mathrm{CH}$ to be supplied. The schemes evaluated for simultaneous production of electricity and cold have managed to reduce up to $64.7 \%$ of primary energy. However, the operating and investment costs of the system remain high. Therefore, they require $\mathrm{CO}_{2}$ taxes to achieve a financial balance with an SPB of fewer than 20 years.

- $\quad$ The CHG polygeneration schemes designed to meet the demand of the ORC generator and the absorption chiller allow reaching solar fractions of up to $84 \%$ with an SPB of fewer than 13 years. The reason is that DHW and heating are obtained from the residual heat of the ORC subsystem.

- The CHGD schemes have been evaluated based on their exergetic performance but, the systems must be studied and adapted to meet energy demand conditions in the industrial and residential sectors. In this sense, district refrigeration systems can be convenient scenarios to assess the viability of the system. On the other hand, the mining industry sector is conditioned to reduce its environmental footprint in extraction processes. In the same way methods for evaluating the economic benefits of reducing $\mathrm{CO}_{2}$ have been extensively detailed; assessing the positive ecological impact of CHGD systems in the mining industry is pertinent.

- In Industries with processes that have different demand levels for cooling, a consensus has not been established regarding heat integration schemes that improve the technical and economic performance of cooling systems powered by thermal energy. In this sense, solar cooling has been partially evaluated for industrial applications, obtaining favorable results in small-scale agriculture and for the wine sector. However, it is necessary to deepen the technological limits and cooling times required by the precooling and crystallization processes in the food industry.

- The solar system made up of collector fields and thermal storage is responsible for the largest share of the investment expenses, which can be as high as $70 \%$. Meanwhile, alternative refrigeration equipment can reach up to $30 \%$ of the initial investment cost. The costs of solar thermal and photovoltaic technologies tend to be updated based on IEA publications, while storage costs are estimated using different methodologies. However, the potential for using thermal refrigeration equipment reported in the literature is based on local prices that, in some cases, are more than eight years old. In this sense, to obtain results with less economic uncertainty, a cost update of thermal cooling equipment is necessary.

- Finally, the economic viability of the systems is subject to balance in the size of the solar field with the savings of primary energy. In this sense, optimization studies focus on 
the system's sizing based on the TMY. However, the industrial trend is in a transition towards a dynamic diagnosis of refrigeration systems. In other words, operation of the system is based on the dynamic prediction of thermal loads to automate energy dispatch strategies and detect cooling system faults. In this sense, it is reasonable to propose forecasting methods that will allow the adaption of alternative refrigeration equipment powered by solar energy.

In summary, future work focused on solar cooling is the integration of Stirling cooling equipment in polygeneration systems and, in turn, determining the viability of hybridization with sorption equipment. Regarding the relationship of the solar resource and the presented polygeneration schemes, it is pertinent to develop selection methods that allow the systems to be adapted to medium and low solar radiation conditions depending on the characteristics of industrial demand. On the other hand, the industries with the most significant potential for integration with CHG schemes are the beverage and food-processing industries due to multiple heat and cold processes. In contrast, underground mines close to the sea have a high potential for implementing CHGD systems. In this regard, it is necessary to develop an optimization method that integrates the benefits of saving water and $\mathrm{CO}_{2}$ without affecting the techno-economic viability of the CHGD systems.

Author Contributions: Conceptualization A.V.-J. and R.A.E.; methodology, A.V.-J. and R.A.E.; formal analysis, J.M.C., M.P.-G. and R.A.E.; investigation, A.V.-J.; writing-original draft preparation, J.M.C., M.P.-G. and R.A.E.; writing-review and editing, J.M.C., M.P.-G. and R.A.E.; visualization, A.V.-J.; supervision, R.A.E.; project administration, J.M.C., M.P.-G. and R.A.E.; funding acquisition, J.M.C., M.P.-G. and R.A.E. All authors have read and agreed to the published version of the manuscript.

Funding: This research was partial funded by National Agency for Research and Development ANID BECAS/DOCTORADO NACIONAL 21200821 and ANID/FONDAP 15110019. The APC was funded by the International Joint Programming Initiative of the State Research Agency (Spain), grant PCI2019-103378 in the framework to the Iberoamerican Program on Science and Technology for the Development (CYTED) project "Microgrids for solar self-supply in isolated productive environments (MICROPROD-SOLAR)", grant ANID P981PTE0258.

Institutional Review Board Statement: Not applicable.

Informed Consent Statement: Not applicable.

Data Availability Statement: Not applicable.

Acknowledgments: The authors wishes to thank Armando Castillejo-Cuberos and Josue F. Rosales for their support during the submission and review stage of the document. A. Villarruel would like to acknowledge the funding from National Agency for Research and Development ANID BECAS/DOCTORADO NACIONAL 21200821 and the International Joint Programming Initiative of the State Research Agency (Spain), grant PCI2019-103378.

Conflicts of Interest: The authors declare no conflict of interest.

\section{References}

1. Paris Agreement. United Nations. In United Nations Treaty Collect; Paris Agreement: Paris, France, 2015.

2. International Energy Agency. World Energy Outlook 2019; IEA publications: Paris, France, 2019.

3. Jazaeri, J.; Gordon, R.L.; Alpcan, T. Influence of building envelopes, climates, and occupancy patterns on residential HVAC demand. J. Build. Eng. 2018, 22, 33-47. [CrossRef]

4. International Energy Agency. The Future of Cooling; IEA publications: Paris, France, 2018.

5. International Energy Agency. Market Report Series: Energy Efficiency 2018, Analysis and Outlooks to 2040; IEA publications: Paris, France, 2018.

6. Kalkan, N.; Young, E.A.; Celiktas, A. Solar thermal air conditioning technology reducing the footprint of solar thermal air conditioning. Renew. Sustain. Energy Rev. 2012, 16, 6352-6383. [CrossRef]

7. Organisation for Economic Co-operation and Development (OECD). Effective Coordination from the Centre: Co-Ordinating Policies to Promote the Transition to a Low-Carbon Economy; OECD: Paris, France, 2015.

8. Geraldi, M.S.; Ghisi, E. Energy \& buildings building-level and stock-level in contrast: A literature review of the energy performance of buildings during the operational stage. Energy Build. 2020, 211, 109810. [CrossRef] 
9. Settino, J.; Sant, T.; Micallef, C.; Farrugia, M.; Spiteri Staines, C.; Licari, J.; Micallef, A. Overview of solar technologies for electricity, heating and cooling production. Renew. Sustain. Energy Rev. 2018, 90, 892-909. [CrossRef]

10. Aliane, A.; Abboudi, S.; Seladji, C.; Guendouz, B. An illustrated review on solar absorption cooling experimental studies. Renew. Sustain. Energy Rev. 2016, 65, 443-458. [CrossRef]

11. Jawahar, C.P.; Saravanan, R. Generator absorber heat exchange based absorption cycle-A review. Renew. Sustain. Energy Rev. 2010, 14, 2372-2382. [CrossRef]

12. Zhai, X.Q.; Qu, M.; Li, Y.; Wang, R.Z. A review for research and new design options of solar absorption cooling systems. Renew. Sustain. Energy Rev. 2011, 15, 4416-4423. [CrossRef]

13. Hüls Güido, W.; Lanser, W.; Petersen, S.; Ziegler, F. Performance of absorption chillers in field tests. Appl. Therm. Eng. 2018, 134, 353-359. [CrossRef]

14. Hassan, H.Z.; Mohamad, A.A.; Alyousef, Y.; Al-Ansary, H.A. A review on the equations of state for the working pairs used in adsorption cooling systems. Renew. Sustain. Energy Rev. 2015, 45, 600-609. [CrossRef]

15. Younes, M.M.; El-Sharkawy, I.I.; Kabeel, A.E.; Saha, B.B. A review on adsorbent-adsorbate pairs for cooling applications. Appl. Therm. Eng. 2017, 114, 394-414. [CrossRef]

16. Attan, D.; Alghoul, M.A.; Saha, B.B.; Assadeq, J.; Sopian, K. The role of activated carbon fiber in adsorption cooling cycles. Renew. Sustain. Energy Rev. 2011, 15, 1708-1721. [CrossRef]

17. Zeyghami, M.; Goswami, D.Y.; Stefanakos, E. A review of solar thermo-mechanical refrigeration and cooling methods. Renew. Sustain. Energy Rev. 2015, 51, 1428-1445. [CrossRef]

18. Getie, M.Z.; Lanzetta, F.; Bégot, S.; Admassu, B.T.; Hassen, A.A. Reversed regenerative Stirling cycle machine for refrigeration application: A review. Int. J. Refrig. 2020, 118, 173-187. [CrossRef]

19. Xu, Z.Y.; Wang, R.Z. Absorption refrigeration cycles: Categorized based on the cycle construction. Int. J. Refrig. 2016, 62, 114-136. [CrossRef]

20. Goyal, P.; Baredar, P.; Mittal, A.; Siddiqui, A.R. Adsorption refrigeration technology—An overview of theory and its solar energy applications. Renew. Sustain. Energy Rev. 2016, 53, 1389-1410. [CrossRef]

21. Edem, K.; Tsoukpoe, N.; Yamegueu, D.; Bassole, J. Solar sorption refrigeration in Africa. Renew. Sustain. Energy Rev. 2014, 35, 318-335. [CrossRef]

22. Kim, D.S.; Ferreira, C.A.I. Solar refrigeration options-A state-of-the-art review. Int. J. Refrig. 2008, 31, 3-15. [CrossRef]

23. Askalany, A.A.; Saha, B.B.; Kariya, K.; Ismail, I.M.; Salem, M.; Ali, A.H.H.; Morsy, M.G. Hybrid adsorption cooling systems-An overview. Renew. Sustain. Energy Rev. 2012, 16, 5787-5801. [CrossRef]

24. Kojok, F.; Fardoun, F.; Younes, R.; Outbib, R. Hybrid cooling systems: A review and an optimized selection scheme. Renew. Sustain. Energy Rev. 2016, 65, 57-80. [CrossRef]

25. Ullah, K.R.; Saidur, R.; Ping, H.W.; Akikur, R.K.; Shuvo, N.H. A review of solar thermal refrigeration and cooling methods. Renew. Sustain. Energy Rev. 2013, 24, 499-513. [CrossRef]

26. Lazzarin, R.M.; Noro, M. Past, present, future of solar cooling: Technical and economical considerations. Sol. Energy 2018, 172, 2-13. [CrossRef]

27. Dieng, A.O.; Wang, R.Z. Literature review on solar adsorption technologies for ice-making and air- conditioning purposes and recent developments in solar technology. Renew. Sustain. Energy Rev. 2001, 5, 313-342. [CrossRef]

28. Eicker, U.; Pietruschka, D.; Haag, M.; Schmitt, A. Systematic design and analysis of solar thermal cooling systems in different climates. Renew. Energy 2015, 80, 827-836. [CrossRef]

29. Prieto, A.; Knaack, U.; Auer, T.; Klein, T. COOLFACADE: State-of-the-art review and evaluation of solar cooling technologies on their potential for façade integration. Renew. Sustain. Energy Rev. 2019, 101, 395-414. [CrossRef]

30. Ghafoor, A.; Munir, A. Worldwide overview of solar thermal cooling technologies. Renew. Sustain. Energy Rev. 2015, 43, 763-774. [CrossRef]

31. Allouhi, A.; Kousksou, T.; Jamil, A.; Bruel, P.; Mourad, Y.; Zeraouli, Y. Solar driven cooling systems: An updated review. Renew. Sustain. Energy Rev. 2015, 44, 159-181. [CrossRef]

32. Alobaid, M.; Hughes, B.; Calautit, J.K.; O'Connor, D.; Heyes, A. A review of solar driven absorption cooling with photovoltaic thermal systems. Renew. Sustain. Energy Rev. 2017, 76, 728-742. [CrossRef]

33. Ge, T.S.; Wang, R.Z.; Xu, Z.Y.; Pan, Q.W.; Du, S.; Chen, X.M.; Ma, T.; Wu, X.N.; Sun, X.L.; Chen, J.F. Solar heating and cooling: Present and future development. Renew. Energy 2018, 126, 1126-1140. [CrossRef]

34. Almasri, R.A.; Abu-Hamdeh, N.H.; Esmaeil, K.K.; Suyambazhahan, S. Thermal solar sorption cooling systems, a review of principle, technology, and applications. Alex. Eng. J. 2021, 61, 367-402. [CrossRef]

35. Campos, P.; Troncoso, L.; Lund, P.D.; Cuevas, C.; Fissore, A.; Garcia, R. Potential of distributed photovoltaics in urban Chile. Sol. Energy 2016, 135, 43-49. [CrossRef]

36. Ferrada, P.; Araya, F.; Marzo, A.; Fuentealba, E. Performance analysis of photovoltaic systems of two different technologies in a coastal desert climate zone of Chile. Sol. Energy 2015, 114, 356-363. [CrossRef]

37. Troncoso, N.; Rojo-gonzález, L.; Vásquez, C.; Rojo-gonzález, L. Economic decision-making tool for a long-term district heat demand forecast panels and storage: The case of Chile. Energy Procedia 2018, 159, 388-393. [CrossRef]

38. Nakahara, N.; Miyakawa, Y.; Yamamoto, M. Experimental study on house cooling and heating with solar energy using flat plate collector. Sol. Energy 1977, 19, 657-662. [CrossRef] 
39. Grossman, G. Solar-powered systems for cooling, dehumidification and air-conditioning. Sol. Energy 2002, 72, 53-62. [CrossRef]

40. Fan, Y.; Luo, L.Ã.; Souyri, B. Review of solar sorption refrigeration technologies: Development and applications. Renew. Sustain. Energy Rev. 2007, 11, 1758-1775. [CrossRef]

41. Kim, D.S.; Infante Ferreira, C.A. Air-cooled LiBr-water absorption chillers for solar air conditioning in extremely hot weathers. Energy Convers. Manag. 2009, 50, 1018-1025. [CrossRef]

42. Anyanwu, E.E.; Ezekwe, C.I. Design, construction and test run of a solid adsorption solar refrigerator using activated carbon/methanol, as adsorbent/adsorbate pair. Energy Convers. Manag. 2003, 44, 2879-2892. [CrossRef]

43. Cleveland, C.J.; Morris, C. Section 39: Refrigeration. In Handbook of Energy; Elsevier: Amsterdam, The Netherlands, 2014; Volume II, pp. 677-682. ISBN 9780124170131.

44. Critoph, R.E.; Zhong, Y. Review of trends in solid sorption refrigeration and heat pumping technology. Proc. J. Process. Mech. Eng. 2005, 219, 285-300. [CrossRef]

45. Tomczyk, J.; Silberstein, E.; Whitman, W.C.; Jhonson, W.M. Refrigeration and Air Conditioning Technology, 8th ed.; Cengage Learning: Boston, MA, USA, 2017; ISBN 978-1-305-57829-6.

46. Cleveland, C.J.; Morris, C. Section 38: HVAC (Heating, Ventilation, Air Conditioning). In Handbook of Energy; Elsevier: Amsterdam, The Netherlands, 2014; Volume II, pp. 669-675, ISBN 9780124170131.

47. Chow, T.T. A review on photovoltaic/thermal hybrid solar technology. Appl. Energy 2010, 87, 365-379. [CrossRef]

48. Daffallah, K.O.; Benghanem, M.; Alamri, S.N.; Joraid, A.A. Experimental evaluation of photovoltaic DC refrigerator under different thermostat settings. Renew. Energy 2017, 113, 1150-1159. [CrossRef]

49. Ferrucci, F.; Stitou, D.; Ortega, P.; Lucas, F. Mechanical compressor-driven thermochemical storage for cooling applications in tropical insular regions. Concept and efficiency analysis. Appl. Energy 2018, 219, 240-255. [CrossRef]

50. Pang, W.; Yu, H.; Zhang, Y.; Yan, H. Solar Photovoltaic based Air Cooling System for Vehicles. Renew. Energy 2019, $130,25-31$. [CrossRef]

51. Eicker, U.; Pietruschka, D.; Schmitt, A.; Haag, M. Comparison of photovoltaic and solar thermal cooling systems for office buildings in different climates. Sol. Energy 2015, 118, 243-255. [CrossRef]

52. Chen, Y.; Liu, Y.; Liu, J.; Luo, X.; Wang, D.; Wang, Y.; Liu, J. Design and adaptability of photovoltaic air conditioning system based on office buildings. Sol. Energy 2020, 202, 17-24. [CrossRef]

53. Aguilar, F.J.; Aledo, S.; Quiles, P.V. Experimental analysis of an air conditioner powered by photovoltaic energy and supported by the grid. Appl. Therm. Eng. 2017, 123, 486-497. [CrossRef]

54. Aguilar, F.; Quiles, P.V. Techno-economic analysis of an air conditioning heat pump powered by photovoltaic panels and the grid. Sol. Energy 2019, 180, 169-179. [CrossRef]

55. Lorenzo, C.; Narvarte, L.; Almeida, R.H.; Cristóbal, A.B. Technical evaluation of a stand-alone photovoltaic heat pump system without batteries for cooling applications. Sol. Energy 2020, 206, 92-105. [CrossRef]

56. Beale, W.; Holmes, W.; Lewis, S.; Cheng, E. Free-Piston Stirling Engines A Progres Report (No. 730647); SAE Technical Paper: Detroit, MI, USA, 1973.

57. Kongtragool, B.; Wongwises, S. A four power-piston low-temperature differential Stirling engine using simulated solar energy as a heat source. Sol. Energy 2008, 82, 493-500. [CrossRef]

58. Mason, J.W.; Stevens, J.W. Characterization of a solar-powered fluidyne test bed. Sustain. Energy Technol. Assess. 2014, 8, 1-8. [CrossRef]

59. Erbay, L.B.; Ozturk, M.M.; Doğan, B. Overall performance of the duplex Stirling refrigerator. Energy Convers. Manag. 2017, 133, 196-203. [CrossRef]

60. Dai, D.; Liu, Z.; Yuan, F.; Long, R.; Liu, W. Finite time thermodynamic analysis of a solar duplex Stirling refrigerator. Appl. Therm. Eng. 2019, 156, 597-605. [CrossRef]

61. Eid, E.I.; Khalaf-Allah, R.A.; Soliman, A.M.; Easa, A.S. Performance of a beta Stirling refrigerator with tubular evaporator and condenser having inserted twisted tapes and driven by a solar energy heat engine. Renew. Energy 2019, 135, 1314-1326. [CrossRef]

62. Langdon-Arms, S.; Gschwendtner, M.; Neumaier, M. A novel solar-powered liquid piston Stirling refrigerator. Appl. Energy 2018, 229, 603-613. [CrossRef]

63. Kongtragool, B.; Wongwises, S. Performance of a twin power piston low temperature differential Stirling engine powered by a solar simulator. Sol. Energy 2007, 81, 884-895. [CrossRef]

64. Cai, Y.; Wang, Y.; Liu, D.; Zhao, F. Thermoelectric cooling technology applied in the field of electronic devices: Updated review on the parametric investigations and model developments. Appl. Therm. Eng. 2019, 148, 238-255. [CrossRef]

65. Huang, B.J.; Chin, C.J.; Duang, C.L. A design method of thermoelectric cooler. Int. J. Refrig. 2000, 23, 208-218. [CrossRef]

66. Sajid, M.; Hassan, I.; Rahman, A. An overview of cooling of thermoelectric devices. Renew. Sustain. Energy Rev. 2017, 78, 15-22. [CrossRef]

67. Manikandan, S.; Kaushik, S.C.; Yang, R. Modified pulse operation of thermoelectric coolers for building cooling applications. Energy Convers. Manag. 2017, 140, 145-156. [CrossRef]

68. Tijani, I.B.; Al Hamadi, A.A.A.; Al Naqbi, K.A.S.S.; Almarzooqi, R.I.M.; Al Rahbi, N.K.S.R. Development of an automatic solar-powered domestic water cooling system with multi-stage Peltier devices. Renew. Energy 2018, 128, 416-431. [CrossRef]

69. Sitorus, T.B.; Lubis, Z.; Ariani, F.; Sembiring, F. Study on thermoelectric cooler driven by solar energy in medan city. Emit. Int. J. Eng. Technol. 2018, 6, 317-327. [CrossRef] 
70. Snyder, G.J.; Toberer, E.S. Complex thermoelectric materials. Nat. Mater. 2008, 7, 105-114. [CrossRef] [PubMed]

71. Date, A.; Date, A.; Dixon, C.; Singh, R.; Akbarzadeh, A. Theoretical and experimental estimation of limiting input heat flux for thermoelectric power generators with passive cooling. Sol. Energy 2015, 111, 201-217. [CrossRef]

72. Li, G.; Shittu, S.; Ma, X.; Zhao, X. Comparative analysis of thermoelectric elements optimum geometry between photovoltaicthermoelectric and solar thermoelectric. Energy 2019, 171, 599-610. [CrossRef]

73. Li, L.; Gao, X.; Zhang, G.; Xie, W.; Wang, F.; Yao, W. Combined solar concentration and carbon nanotube absorber for high performance solar thermoelectric generators. Energy Convers. Manag. 2019, 183, 109-115. [CrossRef]

74. Min, G.; Rowe, D.M. Experimental evaluation of prototype thermoelectric domestic-refrigerators. Appl. Energy 2006, 83, 133-152. [CrossRef]

75. Xu, X.; van Dessel, S.; Messac, A. Study of the performance of thermoelectric modules for use in active building envelopes. Build. Environ. 2007, 42, 1489-1502. [CrossRef]

76. Liu, Z.; Zhang, L.; Gong, G. Experimental evaluation of a solar thermoelectric cooled ceiling combined with displacement ventilation system. Energy Convers. Manag. 2014, 87, 559-565. [CrossRef]

77. Cai, Y.; Wang, L.; Ding, W.T.; Liu, D.; Zhao, F.Y. Thermal performance of an active thermoelectric ventilation system applied for built space cooling: Network model and finite time thermodynamic optimization. Energy 2019, 170, 915-930. [CrossRef]

78. Irshad, K.; Habib, K.; Basrawi, F.; Saha, B.B. Study of a thermoelectric air duct system assisted by photovoltaic wall for space cooling in tropical climate. Energy 2017, 119, 504-522. [CrossRef]

79. Luo, Y.; Zhang, L.; Liu, Z.; Wu, J.; Zhang, Y.; Wu, Z. Performance analysis of a self-adaptive building integrated photovoltaic thermoelectric wall system in hot summer and cold winter zone of China. Energy 2017, 140, 584-600. [CrossRef]

80. Luo, Y.; Zhang, L.; Wu, J.; Liu, Z.; Wu, Z.; He, X. Dynamical simulation of building integrated photovoltaic thermoelectric wall system: Balancing calculation speed and accuracy. Appl. Energy 2017, 204, 887-897. [CrossRef]

81. Luo, Y.; Zhang, L.; Liu, Z.; Wu, J.; Zhang, Y.; Wu, Z. Numerical evaluation on energy saving potential of a solar photovoltaic thermoelectric radiant wall system in cooling dominant climates. Energy 2018, 142, 384-399. [CrossRef]

82. Alomair, Y.; Alomair, M.; Mahmud, S.; Abdullah, H.A. Theoretical and experimental analyses of solar-thermoelectric liquid-chiller system. Int. J. Refrig. 2015, 56, 126-139. [CrossRef]

83. Daghigh, R.; Khaledian, Y. Effective design, theoretical and experimental assessment of a solar thermoelectric cooling-heating system. Sol. Energy 2018, 162, 561-572. [CrossRef]

84. Munday, J.T.; Bagster, D.F. A new ejector theory applied to steam jet refrigeration. Ind. Eng. Chem. Process Des. Dev. 1977, 16, 442-449. [CrossRef]

85. Alexis, G.K.; Karayiannis, E.K. A solar ejector cooling system using refrigerant R134a in the Athens area. Renew. Energy 2005, 30, 1457-1469. [CrossRef]

86. Mukthiyar, S.; Sarath, D.R.; Kumar, B.V.; Madabhushi, A. Design and CFD analysis of R410a refrigerant in convergent nozzle. Mater. Today Proc. 2018, 5, 19463-19470. [CrossRef]

87. Tashtoush, B.; Alshare, A.; Al-Rifai, S. Hourly dynamic simulation of solar ejector cooling system using TRNSYS for Jordanian climate. Energy Convers. Manag. 2015, 100, 288-299. [CrossRef]

88. Allouche, Y.; Varga, S.; Bouden, C.; Oliveira, A.C. Dynamic simulation of an integrated solar-driven ejector based air conditioning system with PCM cold storage. Appl. Energy 2017, 190, 600-611. [CrossRef]

89. Xu, Y.; Wang, C.; Jiang, N.; Song, M.; Wang, Q.; Chen, G. A solar-heat-driven ejector-assisted combined compression cooling system for multistory building-Application potential and effects of floor numbers. Energy Convers. Manag. 2019, 195, 86-98. [CrossRef]

90. Salimpour, M.R.; Ahmadzadeh, A.; Al-Sammarraie, A.T. Comparative investigation on the exergoeconomic analysis of solardriven ejector refrigeration systems. Int. J. Refrig. 2019, 99, 80-93. [CrossRef]

91. Abdulateef, J.M.; Sopian, K.; Alghoul, M.A.; Sulaiman, M.Y. Review on solar-driven ejector refrigeration technologies. Renew. Sustain. Energy Rev. 2009, 13, 1338-1349. [CrossRef]

92. Dennis, M.; Garzoli, K. Use of variable geometry ejector with cold store to achieve high solar fraction for solar cooling. Int. J. Refrig. 2011, 34, 1626-1632. [CrossRef]

93. Dennis, M.; Cochrane, T.; Marina, A. A prescription for primary nozzle diameters for solar driven ejectors. Sol. Energy 2015, 115, 405-412. [CrossRef]

94. Chen, Z.; Jin, X.; Shimizu, A.; Hihara, E.; Dang, C. Effects of the nozzle configuration on solar-powered variable geometry ejectors. Sol. Energy 2017, 150, 275-286. [CrossRef]

95. Vidal, H.; Colle, S.; Pereira, G.D.S. Modelling and hourly simulation of a solar ejector cooling system. Appl. Therm. Eng. 2006, 26, 663-672. [CrossRef]

96. Colle, S.; Pereira, G.S.; Gutiérrez, H.R.V.; Moragas, R.E. On the validity of a design method for a solar-assisted ejector cooling system. Sol. Energy 2009, 83, 139-149. [CrossRef]

97. Varga, S.; Oliveira, A.C.; Palmero-Marrero, A.; Vrba, J. Preliminary experimental results with a solar driven ejector air conditioner in Portugal. Renew. Energy 2017, 109, 83-92. [CrossRef]

98. Tashtoush, B.; Nayfeh, Y. Energy and economic analysis of a variable-geometry ejector in solar cooling systems for residential buildings. J. Energy Storage 2020, 27, 101061. [CrossRef] 
99. Huang, B.J.; Wu, J.H.; Yen, R.H.; Wang, J.H.; Hsu, H.Y.; Hsia, C.J.; Yen, C.W.; Chang, J.M. System performance and economic analysis of solar-assisted cooling/heating system. Sol. Energy 2011, 85, 2802-2810. [CrossRef]

100. Huang, B.J.; Ton, W.Z.; Wu, C.C.; Ko, H.W.; Chang, H.S.; Hsu, H.Y.; Liu, J.H.; Wu, J.H.; Yen, R.H. Performance test of solar-assisted ejector cooling system. Int. J. Refrig. 2014, 39, 172-185. [CrossRef]

101. Bellos, E.; Theodosiou, I.C.; Vellios, L.; Tzivanidis, C. Investigation of a novel solar-driven refrigeration system with ejector Therm. Sci. Eng. Prog. 2018, 8, 284-295. [CrossRef]

102. Bellos, E.; Tzivanidis, C. Optimum design of a solar ejector refrigeration system for various operating scenarios. Energy Convers. Manag. 2017, 154, 11-24. [CrossRef]

103. Śmierciew, K.; Gagan, J.; Butrymowicz, D.; Karwacki, J. Experimental investigations of solar driven ejector air-conditioning system. Energy Build. 2014, 80, 260-267. [CrossRef]

104. Jain, S.; Dhar, P.L.; Katlsmk, S.C. Evaluation of liquid dessicant based evaporative cooling cycles for typical hot and humid climates. Heat Recover. Syst. CHP 1994, 14, 621-632. [CrossRef]

105. Bataineh, K.; Taamneh, Y. Review and recent improvements of solar sorption cooling systems. Energy Build. 2016, $128,22-37$. [CrossRef]

106. Cabrera, F.; Fernández-García, A.; Silva, R.; Pérez-García, M. Use of parabolic trough solar collectors for solar refrigeration and air-conditioning applications. Renew. Sustain. Energy Rev. 2013, 20, 103-118. [CrossRef]

107. Calise, F. High temperature solar heating and cooling systems for different Mediterranean climates: Dynamic simulation and economic assessment. Appl. Therm. Eng. 2012, 32, 108-124. [CrossRef]

108. Calise, F.; Dentice, M.; Vanoli, L. Thermoeconomic optimization of Solar Heating and Cooling systems. Energy Convers. Manag. 2011, 52, 1562-1573. [CrossRef]

109. Shirazi, A.; Taylor, R.A.; Morrison, G.L.; White, S.D. A comprehensive, multi-objective optimization of solar-powered absorption chiller systems for air-conditioning applications. Energy Convers. Manag. 2017, 132, 281-306. [CrossRef]

110. Fong, K.F.; Lee, C.K.; Chow, T.T. Improvement of solar-electric compression refrigeration system through ejector-assisted vapour compression chiller for space conditioning in subtropical climate. Energy Build. 2011, 43, 3383-3390. [CrossRef]

111. Tso, C.Y.; Chan, K.C.; Chao, C.Y.H.; Wu, C.L. Experimental performance analysis on an adsorption cooling system using zeolite 13X/CaCl2 adsorbent with various operation sequences. Int. J. Heat Mass Transf. 2015, 85, 343-355. [CrossRef]

112. Edin Hamrahi, S.; Goudarzi, K.; Yaghoubi, M. Experimental study of the performance of a continues solar adsorption chiller using Nano-activated carbon/methanol as working pair. Sol. Energy 2018, 173, 920-927. [CrossRef]

113. Allouhi, A.; Kousksou, T.; Jamil, A.; El Rhafiki, T.; Mourad, Y.; Zeraouli, Y. Optimal working pairs for solar adsorption cooling applications. Energy 2015, 79, 235-247. [CrossRef]

114. Zhu, L.Q.; Tso, C.Y.; Chan, K.C.; Wu, C.L.; Chao, C.Y.H.; Chen, J.; He, W.; Luo, S.W. Experimental investigation on composite adsorbent-Water pair for a solar-powered adsorption cooling system. Appl. Therm. Eng. 2018, 131, 649-659. [CrossRef]

115. Deshmukh, H.; Maiya, M.P.; Srinivasa Murthy, S. Continuous vapour adsorption cooling system with three adsorber beds. Appl. Therm. Eng. 2015, 82, 380-389. [CrossRef]

116. Duong, X.Q.; Cao, N.V.; Lee, W.S.; Chung, J.D. Module integration in an adsorption cooling system. Appl. Therm. Eng. 2019, 155, 508-514. [CrossRef]

117. Chekirou, W.; Boukheit, N.; Karaali, A. Performance improvement of adsorption solar cooling system. Int. J. Hydrog. Energy 2016, 41, 7169-7174. [CrossRef]

118. Li, C.; Wang, R.Z.; Wang, L.W.; Li, T.X.; Chen, Y. Experimental study on an adsorption icemaker driven by parabolic trough solar collector. Renew. Energy 2013, 57, 223-233. [CrossRef]

119. De Oliveira, R.G.; Generoso, D.J. Influence of the operational conditions on the performance of a chemisorption chiller driven by hot water between $65^{\circ} \mathrm{C}$ and $80^{\circ} \mathrm{C}$. Appl. Energy 2016, 162, 257-265. [CrossRef]

120. Yuan, Y.; Bao, H.; Ma, Z.; Lu, Y.; Roskilly, A.P. Investigation of equilibrium and dynamic performance of SrCl 2 -expanded graphite composite in chemisorption refrigeration system. Appl. Therm. Eng. 2019, 147, 52-60. [CrossRef]

121. Behi, M.; Mirmohammadi, S.A.; Ghanbarpour, M.; Behi, H.; Palm, B. Evaluation of a novel solar driven sorption cooling/heating system integrated with PCM storage compartment. Energy 2018, 164, 449-464. [CrossRef]

122. Garimella, S.; Keinath, C.M.; Delahanty, J.C.; Hoysall, D.C.; Staedter, M.A.; Goyal, A.; Garrabrant, M.A. Development and demonstration of a compact ammonia-water absorption heat pump prototype with microscale features for space-conditioning applications. Appl. Therm. Eng. 2016, 102, 557-564. [CrossRef]

123. Xu, Q.; Lu, D.; Chen, G.; Guo, H.; Dong, X.; Zhao, Y.; Shen, J.; Gong, M. Analysis of an absorption cycle driven by temperaturedistributed heat sources. Appl. Therm. Eng. 2019, 147, 537-544. [CrossRef]

124. Du, S.; Wang, R.Z. A unified single stage ammonia-water absorption system configuration with producing best thermal efficiencies for freezing, air-conditioning and space heating applications. Energy 2019, 174, 1039-1048. [CrossRef]

125. Aprile, M.; Toppi, T.; Guerra, M.; Motta, M. Experimental and numerical analysis of an air-cooled double-lift NH3-H2O absorption refrigeration system. Int. J. Refrig. 2015, 50, 57-68. [CrossRef]

126. Toppi, T.; Aprile, M.; Guerra, M.; Motta, M. Numerical investigation on semi-GAX $\mathrm{NH}_{3}-\mathrm{H}_{2} \mathrm{O}$ absorption cycles. Int. J. Refrig. 2016, 66, 169-180. [CrossRef]

127. Toppi, T.; Aprile, M.; Guerra, M.; Motta, M. Performance assessment of a double-lift absorption prototype for low temperature refrigeration driven by low-grade heat. Energy 2017, 125, 287-296. [CrossRef] 
128. Du, S.; Wang, R.Z.; Chen, X. Analysis on maximum internal heat recovery of a mass-coupled two stage ammonia water absorption refrigeration system. Energy 2017, 133, 822-831. [CrossRef]

129. Xu, Z.Y.; Wang, R.Z. Comparison of absorption refrigeration cycles for efficient air-cooled solar cooling. Sol. Energy 2018, 172, 14-23. [CrossRef]

130. Shi, Y.; Li, F.; Hong, D.; Wang, Q.; Chen, G. Experimental study of a new ejector-absorption refrigeration cycle driven by multi-heat sources. Appl. Therm. Eng. 2018, 133, 604-612. [CrossRef]

131. Bellos, E.; Tzivanidis, C. Parametric analysis and optimization of a cooling system with ejector- absorption chiller powered by solar parabolic trough collectors. Energy Convers. Manag. 2018, 168, 329-342. [CrossRef]

132. Zhou, L.; Li, X.; Zhao, Y.; Dai, Y. Performance assessment of a single/double hybrid effect absorption cooling system driven by linear Fresnel solar collectors with latent thermal storage. Sol. Energy 2017, 151, 82-94. [CrossRef]

133. Huang, B.J.; Wu, J.H.; Hsu, H.Y.; Wang, J.H. Development of hybrid solar-assisted cooling/heating system. Energy Convers. Manag. 2010, 51, 1643-1650. [CrossRef]

134. Gebreslassie, B.H.; Guille, G. Solar assisted absorption cooling cycles for reduction of global warming: A multi-objective optimization approach. Sol. Energy 2012, 86, 2083-2094. [CrossRef]

135. Neyer, D.; Ostheimer, M.; Mugnier, D.; White, S. 10 key principles for successful solar air conditioning design-A compendium of IEA SHC Task 48 experiences. Sol. Energy 2018, 172, 78-89. [CrossRef]

136. Najeh, G.; Slimane, G.; Souad, M.; Riad, B.; Mohammed, E.G. Performance of silica gel-water solar adsorption cooling system. Case Stud. Therm. Eng. 2016, 8, 337-345. [CrossRef]

137. Koronaki, I.P.; Papoutsis, E.G.; Papaefthimiou, V.D. Thermodynamic modeling and exergy analysis of a solar adsorption cooling system with cooling tower in Mediterranean conditions. Appl. Therm. Eng. 2016, 99, 1027-1038. [CrossRef]

138. Palomba, V.; Vasta, S.; Freni, A.; Pan, Q.; Wang, R.; Zhai, X. Increasing the share of renewables through adsorption solar cooling: A validated case study. Renew. Energy 2017, 110, 126-140. [CrossRef]

139. Souissi, M.; Guidara, Z.; Maalej, A. Numerical simulation and experimental investigation on a solar refrigerator with intermittent adsorption cycle. Sol. Energy 2019, 180, 277-292. [CrossRef]

140. Chen, Q.F.; Du, S.W.; Yuan, Z.X.; Sun, T.B.; Li, Y.X. Experimental study on performance change with time of solar adsorption refrigeration system. Appl. Therm. Eng. 2018, 138, 386-393. [CrossRef]

141. Pan, Q.W.; Wang, R.Z. Study on operation strategy of a silica gel-water adsorption chiller in solar cooling application. Sol. Energy 2018, 172, 24-31. [CrossRef]

142. Mendecka, B.; Cozzolino, R.; Leveni, M.; Bella, G. Energetic and exergetic performance evaluation of a solar cooling and heating system assisted with thermal storage. Energy 2019, 176, 816-829. [CrossRef]

143. De Lieto Vollaro, R.; Botta, F.; De Lieto Vollaro, A.; Galli, G. Solar cooling system for buildings: Thermal analysis of solid absorbents applied in low power adsorption system. Energy Build. 2014, 80, 436-440. [CrossRef]

144. Noro, M.; Lazzarin, R.M. Solar cooling between thermal and photovoltaic: An energy and economic comparative study in the Mediterranean conditions. Energy 2014, 73, 453-464. [CrossRef]

145. Ahmed, M.H.; El-Ghetany, H.; Mimet, A.E.; Boushaba, H. Comparison of the thermal performance of solar adsorption cooling system between Egypt and Morocco. Appl. Sol. Energy 2018, 54, 361-368. [CrossRef]

146. Allouhi, A.; Kousksou, T.; Jamil, A.; Agrouaz, Y.; Bouhal, T.; Saidur, R.; Benbassou, A. Performance evaluation of solar adsorption cooling systems for vaccine preservation in Sub-Saharan Africa. Appl. Energy 2016, 170, 232-241. [CrossRef]

147. Cherrad, N.; Benchabane, A.; Sedira, L.; Rouag, A. Transient numerical model for predicting operating temperatures of solar adsorption refrigeration cycle. Appl. Therm. Eng. 2018, 130, 1163-1174. [CrossRef]

148. El Fadar, A. Novel process for performance enhancement of a solar continuous adsorption cooling system. Energy 2016, 114, 10-23. [CrossRef]

149. Pan, Q.W.; Wang, R.Z.; Wang, L.W.; Liu, D. Design and experimental study of a silica gel-water adsorption chiller with modular adsorbers. Int. J. Refrig. 2016, 67, 336-344. [CrossRef]

150. Hirmiz, R.; Lightstone, M.F.; Cotton, J.S. Performance enhancement of solar absorption cooling systems using thermal energy storage with phase change materials. Appl. Energy 2018, 223, 11-29. [CrossRef]

151. Hmida, A.; Chekir, N.; Laafer, A.; Slimani, M.E.A.; Ben Brahim, A. Modeling of cold room driven by an absorption refrigerator in the south of Tunisia: A detailed energy and thermodynamic analysis. J. Clean. Prod. 2019, 211, 1239-1249. [CrossRef]

152. Best, B.R.; Aceves, H.J.M.; Islas, S.J.M.; Manzini, P.F.L.; Pilatowsky, F.I.; Scoccia, R.; Motta, M. Solar cooling in the food industry in Mexico: A case study. Appl. Therm. Eng. 2013, 50, 1447-1452. [CrossRef]

153. Martínez, J.C.; Martinez, P.J.; Bujedo, L.A. Development and experimental validation of a simulation model to reproduce the performance of a 17.6 kW LiBr-water absorption chiller. Renew. Energy 2016, 86, 473-482. [CrossRef]

154. Mansouri, R.; Bourouis, M.; Bellagi, A. Steady state investigations of a commercial diffusion-absorption refrigerator: Experimental study and numerical simulations. Appl. Therm. Eng. 2018, 129, 725-734. [CrossRef]

155. Bellos, E.; Tzivanidis, C.; Antonopoulos, K.A. Exergetic, energetic and financial evaluation of a solar driven absorption cooling system with various collector types. Appl. Therm. Eng. 2016, 102, 749-759. [CrossRef]

156. Bagheri, B.S.; Shirmohammadi, R.; Mahmoudi, S.M.S.; Rosen, M.A. Optimization and comprehensive exergy-based analyses of a parallel flow double-effect water-lithium bromide absorption refrigeration system. Appl. Therm. Eng. 2019, 152, $643-653$. [CrossRef] 
157. Hang, Y.; Qu, M.; Winston, R.; Jiang, L.; Widyolar, B.; Poiry, H. Experimental based energy performance analysis and life cycle assessment for solar absorption cooling system at University of Californian, Merced. Energy Build. 2014, 82, 746-757. [CrossRef]

158. Garimella, S.; Ponkala, M.J.; Goyal, A.; Staedter, M.A. Waste-heat driven ammonia-water absorption chiller for severe ambient operation. Appl. Therm. Eng. 2019, 154, 442-449. [CrossRef]

159. Phelan, P.; Varsamopoulos, G.; Sherbeck, J.; Gupta, S.K.S.; Haywood, A. Thermodynamic feasibility of harvesting data center waste heat to drive an absorption chiller. Energy Convers. Manag. 2012, 58, 26-34. [CrossRef]

160. Alghool, D.M.; Elmekkawy, T.Y.; Haouari, M.; Elomri, A. Optimization of design and operation of solar assisted district cooling systems. Energy Convers. Manag. X 2020, 6, 100028. [CrossRef]

161. Mussati, S.F.; Cignitti, S.; Mansouri, S.S.; Gernaey, K.V.; Morosuk, T.; Mussati, M.C. Configuration optimization of series flow double-effect water-lithium bromide absorption refrigeration systems by cost minimization. Energy Convers. Manag. 2018, 158, 359-372. [CrossRef]

162. Bouhal, T.; Fertahi, S.E.-D.; Agrouaz, Y.; El Rhafiki, T.; Kousksou, T.; Zeraouli, Y.; Jamil, A. Technical assessment, economic viability and investment risk analysis of solar heating/cooling systems in residential buildings in Morocco. Sol. Energy 2018, 170, 1043-1062. [CrossRef]

163. Wang, H.; Peterson, R.; Herron, T. Design study of configurations on system COP for a combined ORC (organic Rankine cycle) and VCC (vapor compression cycle). Energy 2011, 36, 4809-4820. [CrossRef]

164. Kutlu, C.; Erdinc, M.T.; Li, J.; Wang, Y.; Su, Y. A study on heat storage sizing and flow control for a domestic scale solar-powered organic Rankine cycle-vapour compression refrigeration system. Renew. Energy 2019, 143, 301-312. [CrossRef]

165. Wu, D.; Aye, L.; Ngo, T.; Mendis, P. Optimisation and financial analysis of an organic Rankine cycle cooling system driven by facade integrated solar collectors. Appl. Energy 2017, 185, 172-182. [CrossRef]

166. Luo, Y.; Zhang, L.; Liu, Z.; Wang, Y.; Meng, F.; Wu, J. Thermal performance evaluation of an active building integrated photovoltaic thermoelectric wall system. Appl. Energy 2016, 177, 25-39. [CrossRef]

167. He, W.; Zhou, J.; Hou, J.; Chen, C.; Ji, J. Theoretical and experimental investigation on a thermoelectric cooling and heating system driven by solar. Appl. Energy 2013, 107, 89-97. [CrossRef]

168. Khaliq, A.; Kumar, R.; Mokheimer, E.M.A. Investigation on a solar thermal power and ejector-absorption refrigeration system based on first and second law analyses. Energy 2018, 164, 1030-1043. [CrossRef]

169. Roumpedakis, T.C.; Christou, T.; Monokrousou, E.; Braimakis, K.; Karellas, S. Integrated ORC-Adsorption cycle: A first and second law analysis of potential configurations. Energy 2019, 179, 46-58. [CrossRef]

170. Olabomi, R.A.; Jaafar, A.B.; Musa, M.N.; Sarip, S.; Ariffin, A. Techno-economic analysis of innovative production and application of solar thermal chilled water for agricultural soil cooling. Renew. Sustain. Energy Rev. 2017, 73, 215-224. [CrossRef]

171. Shabgard, H.; Song, L.; Zhu, W. Heat transfer and exergy analysis of a novel solar-powered integrated heating, cooling, and hot water system with latent heat thermal energy storage. Energy Convers. Manag. 2018, 175, 121-131. [CrossRef]

172. Ayadi, O.; Al-dahidi, S. Comparison of solar thermal and solar electric space heating and cooling systems for buildings in different climatic regions. Sol. Energy 2019, 188, 545-560. [CrossRef]

173. Calise, F. Thermoeconomic analysis and optimization of high efficiency solar heating and cooling systems for different Italian school buildings and climates. Energy Build. 2010, 42, 992-1003. [CrossRef]

174. Ghaith, F.A.; Razzaq, H. Performance of solar powered cooling system using Parabolic Trough Collector in UAE. Sustain. Energy Technol. Assess. 2017, 23, 21-32. [CrossRef]

175. Xie, F.; Liu, H.; Gu, X.; Li, P.; Chen, W.; Ling, P. Matching suitability of solar-biomass hybrid absorption cooling system for ecological restaurants in different regions. Procedia Eng. 2017, 205, 672-679. [CrossRef]

176. Murray, C.; Quiñones, G.; Cortés, F.; Escobar, R.; Cardemil, J.M. Solar assisted absorption machine for the fermentation cooling and maceration heating processes in the winemaking industry. Energy Procedia 2016, 91, 805-814. [CrossRef]

177. Ahn, H.; Freihaut, J.D.; Rim, D. Economic feasibility of combined cooling, heating, and power (CCHP) systems considering electricity standby tariffs. Energy 2019, 169, 420-432. [CrossRef]

178. Bilardo, M.; Ferrara, M.; Fabrizio, E. Performance assessment and optimization of a solar cooling system to satisfy Renewable Energy Ratio (RER) requirements in multi-family. Renew. Energy 2020, 155, 990-1008. [CrossRef]

179. ElHelw, M.; ElHefni, A.A. Novel thermoelectric cell-enthalpy wheel air conditioning system integrated with solar panels. Sol. Energy 2018, 176, 526-534. [CrossRef]

180. Buonomano, A.; Calise, F.; Palombo, A. Solar heating and cooling systems by absorption and adsorption chillers driven by stationary and concentrating photovoltaic/thermal solar collectors: Modelling and simulation. Renew. Sustain. Energy Rev. 2018, 82, 1874-1908. [CrossRef]

181. Lu, Z. Experimental and simulation analysis of the combined adsorption system driven by $80-140{ }^{\circ} \mathrm{C}$ heat source. Energy Convers. Manag. 2019, 184, 726-734. [CrossRef]

182. Sheykhi, M.; Chahartaghi, M.; Balakheli, M.M.; Kharkeshi, B.A.; Miri, S.M. Energy, exergy, environmental, and economic modeling of combined cooling, heating and power system with Stirling engine and absorption chiller. Energy Convers. Manag. 2019, 180, 183-195. [CrossRef]

183. Neyer, D.; Ostheimer, M.; Hauer, N.; Halmdienst, C.; Pink, W. Application of an adapted single-/half- effect NH3/H2O absorption chiller in tri-generation and solar cooling systems. Sol. Energy 2018, 173, 715-727. [CrossRef] 
184. Neyer, D.; Ostheimer, M.; Dipasquale, C.; Köll, R. Technical and economic assessment of solar heating and cooling-Methodology and examples of IEA SHC Task 53. Sol. Energy 2018, 172, 90-101. [CrossRef]

185. Zeng, R.; Zhang, X.; Deng, Y.; Li, H.; Zhang, G. Optimization and performance comparison of combined cooling, heating and power/ground source heat pump/photovoltaic/solar thermal system under different load ratio for two operation strategies. Energy Convers. Manag. 2020, 208, 112579. [CrossRef]

186. Buonomano, A.; Calise, F.; Palombo, A.; Vicidomini, M. Energy and economic analysis of geothermal-solar trigeneration systems: A case study for a hotel building in Ischia. Appl. Energy 2015, 138, 224-241. [CrossRef]

187. Wang, J.; Ma, C.; Wu, J. Thermodynamic analysis of a combined cooling, heating and power system based on solar thermal biomass gasification. Appl. Energy 2019, 247, 102-115. [CrossRef]

188. Sameti, M.; Haghighat, F. Hybrid solar and heat-driven district cooling system: Optimal integration and control strategy. Sol. Energy 2019, 183, 260-275. [CrossRef]

189. Mehrpooya, M.; Ghorbani, B.; Hosseini, S.S. Thermodynamic and economic evaluation of a novel concentrated solar power system integrated with absorption refrigeration and desalination cycles. Energy Convers. Manag. 2018, 175, 337-356. [CrossRef]

190. Praveen Kumar, G.; Saravanan, R.; Coronas, A. Simulation studies on simultaneous power, cooling and purified water production using vapour absorption refrigeration system. Appl. Therm. Eng. 2018, 132, 296-307. [CrossRef]

191. Leiva-illanes, R.; Escobar, R.; Cardemil, J.M.; Alarcón-padilla, D. Comparison of the levelized cost and thermoeconomic methodologies-Cost allocation in a solar polygeneration plant to produce power, desalted water, cooling and process heat. Energy Convers. Manag. 2018, 168, 215-229. [CrossRef]

192. Leiva-illanes, R.; Escobar, R.; Cardemil, J.M.; Alarcón-padilla, D.; Uche, J.; Martínez, A. Exergy cost assessment of CSP driven multi-generation schemes: Integrating seawater desalination, refrigeration, and process heat plants. Energy Convers. Manag. 2019, 179, 249-269. [CrossRef]

193. Ali, E.S.; Harby, K.; Askalany, A.A.; Diab, M.R.; Alsaman, A.S. Weather effect on a solar powered hybrid adsorption desalinationcooling system: A case study of Egypt's climate. Appl. Therm. Eng. 2017, 124, 663-672. [CrossRef]

194. Rezk, H.; Alsaman, A.S.; Al-Dhaifallah, M.; Askalany, A.A.; Abdelkareem, M.A.; Nassef, A.M. Identifying optimal operating conditions of solar-driven silica gel based adsorption desalination cooling system via modern optimization. Sol. Energy 2019, 181, 475-489. [CrossRef]

195. The World Bank/SolarGis; Global Solar Atlas 2.0, Solar resource data: Solargis (2020). Available online: https: / / solargis.com/ maps-and-gis-data/download/world (accessed on 3 August 2021).

196. Zhu, Z.; Geng, Y.; Sun, D. Effects of operation processes and conditions on enhancing performances of vacuum cooling of foods: A review. Trends Food Sci. Technol. 2019, 85, 67-77. [CrossRef]

197. Nguyen, V.; Rimaux, T.; Truong, V.; Dewettinck, K.; van Bockstaele, F. The effect of cooling on crystallization and physico-chemical properties of puff pastry shortening made of palm oil and anhydrous milk fat blends. J. Food Eng. 2021, 291, 110245. [CrossRef]

198. Efstratiadi, M.; Acha, S.; Shah, N.; Markides, C.N. Analysis of a closed-loop water-cooled refrigeration system in the food retail industry: A UK case study. Energy 2019, 174, 1133-1144. [CrossRef]

199. Catrini, P.; Panno, D.; Cardona, F.; Piacentino, A. Characterization of cooling loads in the wine industry and novel seasonal indicator for reliable assessment of energy saving through retro fit of chillers. Appl. Energy 2020, 266, 114856. [CrossRef]

200. Pingye, G.; Yanwei, W.; Mengmeng, D.; Dongyang, P.; Nan, L. Research and application of methods for effectiveness evaluation of mine cooling system. Int. J. Min. Sci. Technol. 2020, 25. [CrossRef]

201. Belle, B.; Biffi, M. Cooling pathways for deep Australian longwall coal mines of the future. Int. J. Min. Sci. Technol. 2018, 28, 865-875. [CrossRef]

202. Feng, X.; Jia, Z.; Liang, H.; Wang, Z.; Wang, B.; Jiang, X. A full air cooling and heating system based on mine water source. Appl. Therm. Eng. 2018, 145, 610-617. [CrossRef]

203. Edgar, G.; Plessis, D.; Liebenberg, L.; Mathews, E.H. The use of variable speed drives for cost-effective energy savings in South African mine cooling systems. Appl. Energy 2020, 111, 16-27. [CrossRef]

204. Bornman, W.; Dirker, J.; Arndt, D.C.; Meyer, J.P. Integrated energy simulation of a deep level mine cooling system through a combination of forward and first-principle models applied to system-side parameters. Appl. Therm. Eng. 2017, 123, 1166-1180. [CrossRef] 